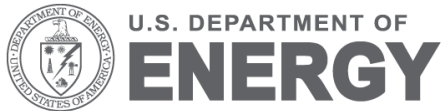

Prepared for the U.S. Department of Energy

\title{
Initial Assessment of U.S. Refineries for Purposes of Potential Bio-Based Oil Insertions
}

CJ Freeman

SB Jones

AB Padmaperuma

M Santosa

C Valkenburg

J Shinn (retired Chevron)

April 2013

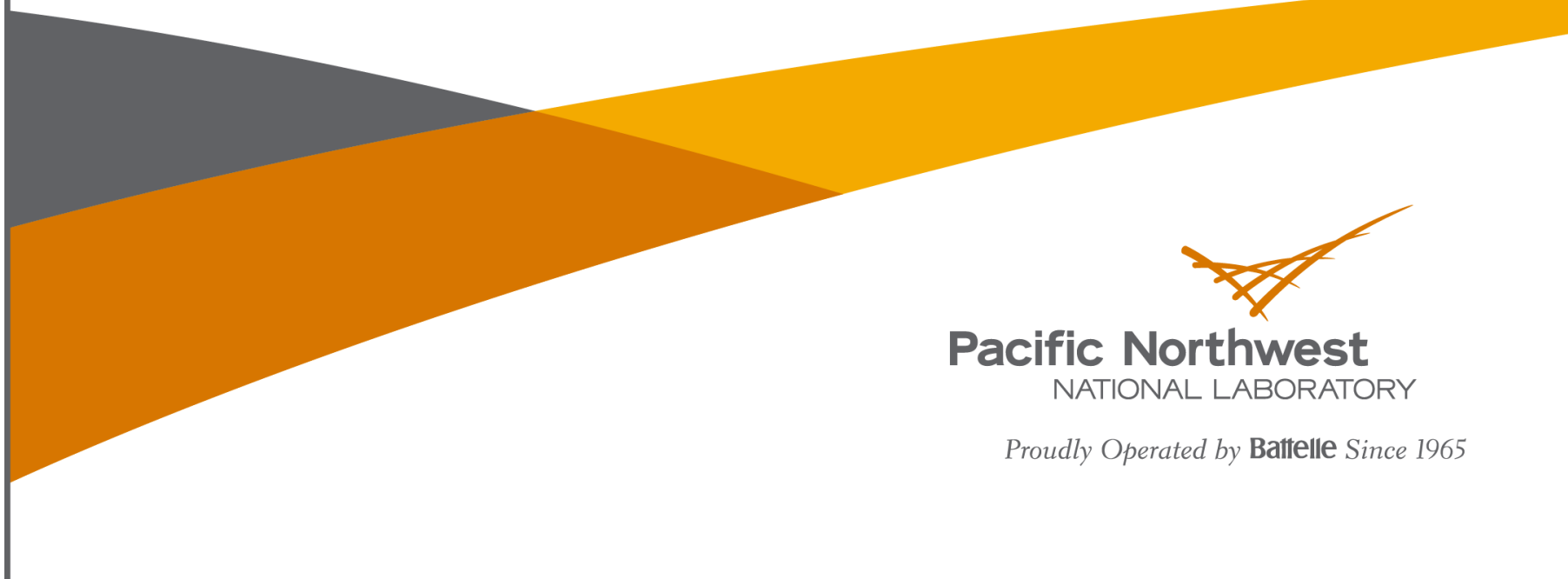




\title{
DISCLAIMER
}

This report was prepared as an account of work sponsored by an agency of the United States Government. Neither the United States Government nor any agency thereof, nor Battelle Memorial Institute, nor any of their employees, makes any warranty, express or implied, or assumes any legal liability or responsibility for the accuracy, completeness, or usefulness of any information, apparatus, product, or process disclosed, or represents that its use would not infringe privately owned rights. Reference herein to any specific commercial product, process, or service by trade name, trademark, manufacturer, or otherwise does not necessarily constitute or imply its endorsement, recommendation, or favoring by the United States Government or any agency thereof, or Battelle Memorial Institute. The views and opinions of authors expressed herein do not necessarily state or reflect those of the United States Government or any agency thereof.

\author{
PACIFIC NORTHWEST NATIONAL LABORATORY \\ operated by \\ BATTELLE \\ for the \\ UNITED STATES DEPARTMENT OF ENERGY \\ under Contract DE-AC05-76RL01830
}

Printed in the United States of America
Available to DOE and DOE contractors from the Office of Scientific and Technical Information,
P.O. Box 62, Oak Ridge, TN 37831-0062;
ph: (865) 576-8401
fax: $(865)$ 576-5728
email: reports@adonis.osti.gov

\begin{abstract}
Available to the public from the National Technical Information Service, U.S. Department of Commerce, 5285 Port Royal Rd., Springfield, VA 22161 ph: (800) 553-6847 fax: $(703) 605-6900$ email: orders@ntis.fedworld.gov online ordering: http://www.ntis.gov/ordering.htm
\end{abstract}

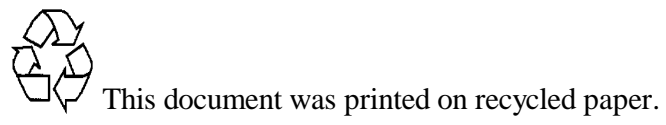




\title{
Initial Assessment of U.S. Refineries for Purposes of Potential Bio-Based Oil Insertions
}

\author{
CJ Freeman \\ SB Jones \\ AB Padmaperuma \\ M Santosa \\ C Valkenburg \\ J Shinn (independent contractor, retired Chevron)
}

April 2013

Prepared for the U.S. Department of Energy

under Contract DE-AC05-76RL01830

Pacific Northwest National Laboratory

Richland, Washington 99352 
In order to meet U.S. biofuel objectives over the coming decade the conversion of a broad range of biomass feedstocks, using diverse processing options, will be required. Further, the production of both gasoline and diesel biofuels will employ biomass conversion methods that produce wide boiling range intermediate oils requiring treatment similar to conventional refining processes (i.e. fluid catalytic cracking, hydrocracking, and hydrotreating). As such, it is widely recognized that leveraging existing U.S. petroleum refining infrastructure is key to reducing overall capital demands. This study examines how existing U.S. refining location, capacities and conversion capabilities match in geography and processing capabilities with the needs projected from anticipated biofuels production.

At a national level, there appears to be adequate conversion and hydrotreating facilities in existing refineries to process anticipated bio-derived oils into transportation fuels. However, numerous concerns are apparent, including:

- a potential shortfall in both overall hydrotreating capacity and hydrogen production capacity in refineries to manage the conversion of certain biomass derived intermediates having high oxygen content;

- a regional concentration of anticipated biofuel resources, placing added stress in particular refining regions (e.g. the Gulf Coast);

- uncertainties surrounding the impact of biomass derived intermediates on the refiner's ability to meet product performance and product quantity demands, and the need for better and more comprehensive chemical composition information;

- the need for considerably more data and experience on the behavior of projected biofuels intermediates in refining processes (e.g. impacts on process performance and reliability); and

- the need to examine the optimum capital investment locations for additional processing equipment. For example, whether it is better to produce finished biofuels at the new production sites, or whether existing refining facilities should be expanded to better handle a more 'raw' bio-oil intermediate.

Responding to these concerns may be best accomplished by creating a strong collaboration between the refining industry and the national programs that are working in the field of biomass research. The intent is to identify priorities and opportunities for filling critical knowledge and experience gaps and directing investments in a manner that best supports biofuels objectives. 


\section{Contents}

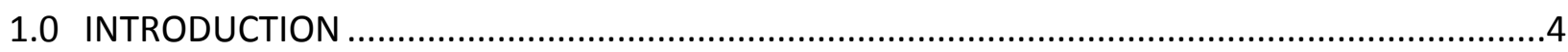

2.0 ASSESSMENT OF U.S. BIOMASS AVAILABILITY VERSUS REFINERY LOCATION .......................5

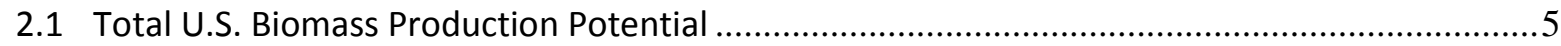

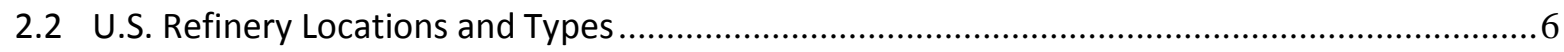

2.3 Biomass Availability in Proximity to Existing U.S. Refineries ................................................... 8

3.0 IMPACT OF BIO-BASED INTERMEDIATES ON REFINERY OPERATIONS.............................12

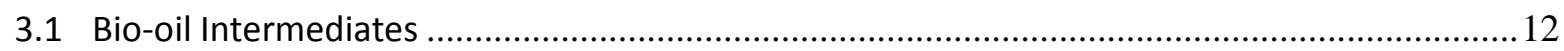

3.2 Estimates of Natural Gas for Hydrotreating Bio-oils ............................................................ 13

3.3 Co-processing of Bio-oil Intermediates in Refinery Units ...................................................... 14

3.4 The Refiner's Perspective on New Feedstocks - General ...................................................... 15

3.5 The Refiner's Perspective on Biomass-based Feedstocks ..................................................... 16

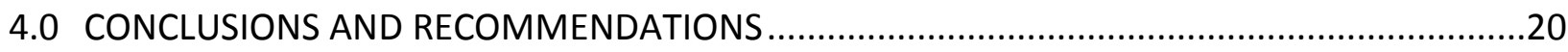

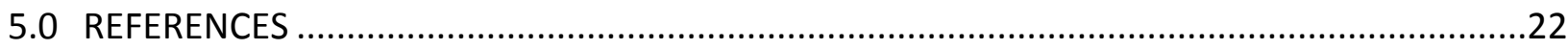

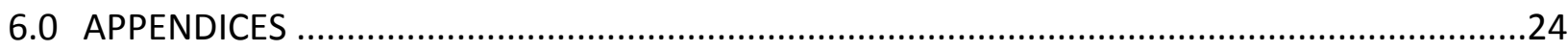




\subsection{INTRODUCTION}

The U.S. DOE EERE Bioenergy Technologies Office (BETO) is tasked with enabling the production of biofuels through research, development, demonstration, and deployment. In order to meet U.S. biofuel objectives over the coming decade the conversion of a broad range of biomass feedstocks, using diverse processing options, will be required. Further, the production of both gasoline and diesel biofuels will employ biomass conversion methods that produce wide boiling range intermediates requiring treatment similar to conventional refining processes (i.e. fluid catalytic cracking, hydrocracking, and hydrotreating). As such, it is widely recognized that leveraging existing U.S. petroleum refining infrastructure is key to reducing overall capital demands. The National Advanced Biofuels Consortium, for example, is researching specific biomass conversion pathways and how they might integrate into a refinery ${ }^{[1]}$

The purpose of this study is to support the DOE BETO goals through a high-level assessment of the impact on current U.S. refining capacity to accommodate partially converted biomass to biofuel intermediates, rather than rely on stand-alone biorefineries to produce finished fuels. This study examines how existing U.S. refining locations, capacities and conversion capabilities match in geography and processing capability with the needs projected from anticipated biofuels production. It is meant to serve as an initial guide for determining subsequent steps in technology development, testing and commercial deployment for U.S. refiners.

The basis for this study is:

- the Energy Independence and Security Act (EISA) of 2007 volumetric targets for 2022,

- the Billion Ton Study as stored in the Knowledge Discovery Framework (KDF) database of biomass resources,

- the Energy Information Agency (EIA) database of U.S. refining locations, capacities and conversion capabilities,

- publically available quality data for bio-oil intermediates, and

- review by a long-time member of the petroleum refining community.

The existing U.S. national Renewable Fuel Standard (RFS) Program was developed to increase the volume of renewable fuel that is blended into transportation fuels. The Energy Independence and Security Act (EISA) of 2007 increased and expanded the standard such that, by 2022, 36 billion gallons of renewable fuel must be used per year ${ }^{[2]}$ This volume target also requires 21 billion gallons of the renewable fuel to be "advanced biofuel" in origin, which not only means renewables other than corn derived ethanol, but biofuels that achieve greenhouse gas reductions of at least $50 \%$ over the 2005 baseline petroleum-derived fuels. Within the constraints of these volumetric targets, the first step is to evaluate all U.S. biomass sources in proximity to the current U.S. refineries. After that, the impact of those sources on each refinery can be assessed, based on their current conversion infrastructure, estimated loading limits, and basic impact to products produced. These steps, and corresponding results and recommendations for future study, are described in the following sections. 


\subsection{ASSESSMENT OF U.S. BIOMASS AVAILABILITY VERSUS REFINERY LOCATION}

\subsection{Total U.S. Biomass Production Potential}

In order to assess the impacts of biofuels on U.S. refineries, the first step is to understand the forecasted production of biomass based on individual sources and geographies. The Bioenergy Knowledge Discovery Framework (KDF) ${ }^{[3]}$, developed by several national laboratories and universities under sponsorship from DOE's

Biomass Technologies Office, and the data derived from the updated Billion Ton Study ${ }^{[4]}$ stored therein, is used for the initial assessment[3]

The biomass projections from the Billion Ton Study used in this report include all U.S. resources, in all geographies, excluding Hawaii and Alaska. These projections assume the 2022 forecasts and at an average price of $\$ 60$ per dry ton at farm gate (crop residues and energy crops) or landing (forest resources). This price point does not include pre-processing, handling, transportation, and storage. Although average pricing is assumed, it is understood that individual feedstock prices will vary significantly by type, geography, conversion system requirements, and technology requirements. The $\$ 60$ per ton value was used in the Billion Ton Study because it "represents a realistic, reasonable price for discussion purposes" ${ }^{[4]}$. Note that the Billion Ton baseline scenario assumption is a continuation of the U.S. Department of Agriculture (USDA) 10-year forecast for the major food and forage crops through 2030. Within the Billion Ton Study, the supply of crop residue is modeled simultaneously with energy crops as they will compete for land use. Yield improvements over time are incorporated into Billion Ton Study projections. Cases run for this study are simulated under the "baseline" yield scenario as accessed through the KDF. As such, the average annual corn yield increase estimate is slightly more than $1 \%$ over the 20 -year simulation period. The energy crop yields are assumed to have an annual increase of 1\%. In compliance with EISA, all resources on federal lands are excluded. Note that the Billion Ton data takes into account "the importance of...residue in maintaining soil nutrients and carbon levels and to control erosion" for sustainability ${ }^{[3]}[4]$

Table 2.1 shows a summary of the U.S. biomass projections from the Billion Ton Study via the KDF database. Here the biomass resources are categorized into the four primary feedstock classes: crop residues, energy crops, forest residues, and wood wastes. Algal sources of biofuel are not included. The biofuel yield projections in Table 2.1 are estimated by adding an additional loss of $20 \%$ for each feedstock due to handling and storage losses, and applying an 85-gallon (finished fuel blendstock)-per-dry-ton conversion factor on each biomass source. This is the same assumption used for the baseline estimates in the Billion Ton Study. The actual conversion factors will vary with time, region, choice of conversion pathways, and feedstock type (e.g. composition, ash content).

The projections in Table 2.1 show a total of more than 40 billion gallons of biofuel per year (bgy) for all feedstock types, which is in line with the EISA goal. Of the total biofuel projection, $47 \%$ is from energy crops, $26 \%$ from crop residues, and the remaining is nearly equally split between forest residues and wood wastes. The largest individual sources are perennial grasses and corn stover, which are $31 \%$ and $20 \%$ of the total projected biofuel projection, respectively.

The feedstock distributions in Table 2.1 indicate that no single biomass source will be adequate to obtain the EISA goal. Also, the availability of certain feedstock classes are localized to certain parts of the country. The crop residues are mostly abundant in the American Mid-Western states, with lowa, Nebraska, and Illinois leading the nation in availability. The projected energy crop availability is centered on Texas, Oklahoma, and 
Kansas, with some in the other Gulf-states. A study conducted by the Global Energy Management Institute, came to a similar conclusion ${ }^{[5]}$. The majority of the forestry resources are available in the Gulf Coast states, southern states, and in the Pacific Northwest. Although wood waste is available in every state the largest availability is in California and in Texas. The wood wastes from cotton, rice, sugar cane, and wheat are localized to the states that produce those crops.

Table 2.1 Summary of all available U.S. biomass feedstock types.

Based on KDF database information at \$60/dry ton for the year 2022 under baseline assumptions (where applicable), and the assumed yield for hydrocarbon liquid fuels.

\begin{tabular}{|c|c|c|}
\hline & $\begin{array}{c}\text { Feedstock Production } \\
\text { (million dry tons per year) }\end{array}$ & $\begin{array}{c}\text { Biofuel yield } \\
\text { (bgy) }\end{array}$ \\
\hline \multicolumn{3}{|l|}{ Crop Residues } \\
\hline Corn stover & 120 & 8.2 \\
\hline Wheat straw & 32 & 2.1 \\
\hline Barley straw & 1.9 & 0.1 \\
\hline Sorghum stubble & 0.6 & 0.04 \\
\hline Oat straw & 0.02 & 0.00 \\
\hline Sub Total (rounded) & 154 & 10 \\
\hline \multicolumn{3}{|l|}{ Energy Crops } \\
\hline Perennial grasses & 188 & 13 \\
\hline Woody crops & 84 & 5.7 \\
\hline Annual energy crop & 9.8 & 0.7 \\
\hline Sub Total (rounded) & 282 & 19 \\
\hline \multicolumn{3}{|l|}{ Forest Resources } \\
\hline Logging residues & 45 & 3.1 \\
\hline Integrated composite operations & 35.3 & 2.4 \\
\hline Other removal residue & 12.5 & 0.85 \\
\hline Treatment thinnings of other forest land & 1.8 & 0.12 \\
\hline Sub Total (rounded) & 95 & 6.4 \\
\hline \multicolumn{3}{|l|}{ Wood Waste } \\
\hline Urban wood waste, construction and demo & 24 & 1.6 \\
\hline Urban wood waste, municipal solid waste & 11 & 0.73 \\
\hline Mill residue, unused secondary & 7.5 & 0.51 \\
\hline Rice straw & 7.4 & 0.50 \\
\hline Orchard and vineyard prunings & 5.5 & 0.38 \\
\hline Cotton residue & 5.9 & 0.40 \\
\hline Cotton gin trash & 1.7 & 0.11 \\
\hline Rice hulls & 1.7 & 0.11 \\
\hline Mill residue, unused primary & 1.4 & 0.09 \\
\hline Sugarcane trash & 1.1 & 0.08 \\
\hline Wheat dust & 0.58 & 0.04 \\
\hline Sub Total (rounded) & 67 & 4.5 \\
\hline Total (rounded) & 597 & 41 \\
\hline
\end{tabular}

\subsection{U.S. Refinery Locations and Types}

The U.S. Energy Information Administration (EIA) has compiled data for 149 individual U.S. refineries. The latest available EIA data set is as of January 1, $2011^{[6]}$ Table A.1 gives a complete list of the EIA refineries and 
associated process data. The available data include primary crude capacity as well as average stream rates for primary unit operations. Twelve percent of the refineries lack significant enough information to be useful (e.g. no capacities listed, or no resolution on resulting product streams). However, the combined capacity of those plants is less than five percent of the total, thus their omission should not greatly impact the overall conclusions. The remaining 136 refineries are used for this analysis. The total distillation capacity of the referenced refineries is 19.5 million barrels per (stream) day. Roughly compared, the 36 billion gallon per year EISA-RFP target for biofuels equates to approximately $12 \%$ of this total current crude distillation capacity.

Next, the refineries in the EIA data set were categorized based on their flexibility in handling bio-oil intermediates. The ability to convert higher boiling-range materials into lower boiling range materials is the primary capability needed in a refinery to convert many bio-oil intermediates into conventional petroleum products. These conversions are typically achieved through fluid catalytic cracking (FCC) or hydrocracking. The removal of elements, especially oxygen, is the next most critical capability a refinery would need to handle biooil intermediates. Hydrotreating is the primary means for oxygen and trace element removal in a refinery. Using this criteria, the U.S. refineries in the EIA database were grouped based on conversion and hydrotreating capability. Figure 2.1 shows the individual breakdown of categories chosen, along with the number of refineries in the EIA data base corresponding to each.

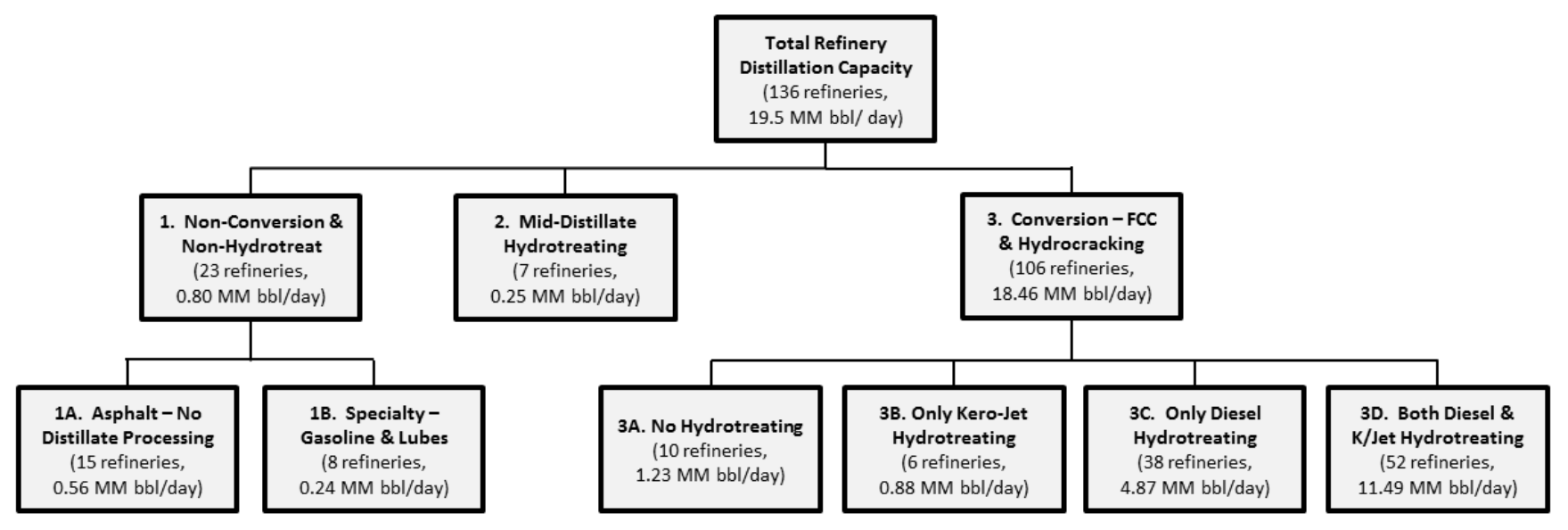

Figure 2.1. Categorization of U.S. Refineries in EIA Based on Relevance to Biomass Production

Figure 2.1 shows 23 refineries in Category 1, which represents refineries with no conversion or hydrotreating capability. These refineries are considered to have no real value in handling biofuels other than blending fully converted and treated intermediates. There are 7 refineries shown in Category 2, which is represented by those with mid-distillate hydrotreating only, without any conversion capabilities for heavier distillate fractions. Category 3 refineries are those with some conversion capability (FCC and/or hydrocracking) and some range of hydrotreating capability. This class of refineries, 106 in total, is considered to be the mostly likely suited for some level biofuel processing due to the requisite conversion capability in place. Within Category 3 there are four sub categories listed reflecting the various levels of hydrotreating capabilities. Here, Category 3D represents the most extensive hydrotreating for potential biofuels production, covering both diesel and jet fractions. Category 3D is represented by 52 U.S. refineries today, and over half of the overall U.S. capacity. 


\subsection{Biomass Availability in Proximity to Existing U.S. Refineries}

Next, the locations of the candidate (Category 3 ) refineries are compared to the corresponding biomass availability. Figure 2.2 shows a map of the U.S. refineries in the current EIA database, with each of the categories described in the previous section. Although this map shows a concentration of Category 3 refineries in the gulf area, this refinery class is still spread across most of the U.S. However, there is a lack of Category 3 refineries in many of the areas with the most biomass (e.g. the corn-belt, the south east coast, and the northwest). In order to assess feedstock proximity to refinery locations, the KDF tool and related assumptions described in Section 2.1, are used. Figure 2.3 shows a map of the total projected biomass from the KDF based on state averages.

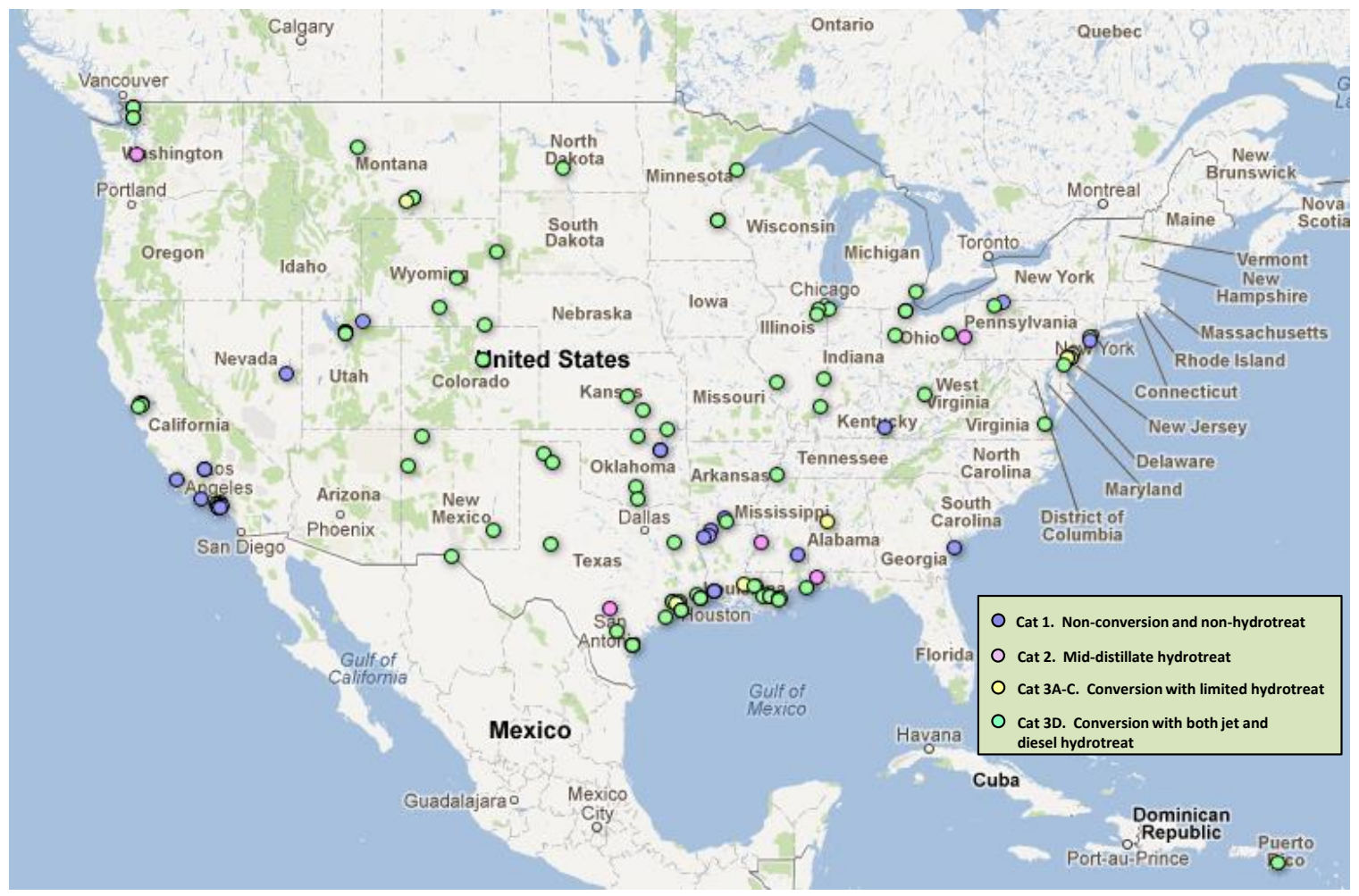

Figure 2.2. Map of U.S. Refineries in 2011 EIA Database based on Categories Reflecting Biofuel Processing Potential 


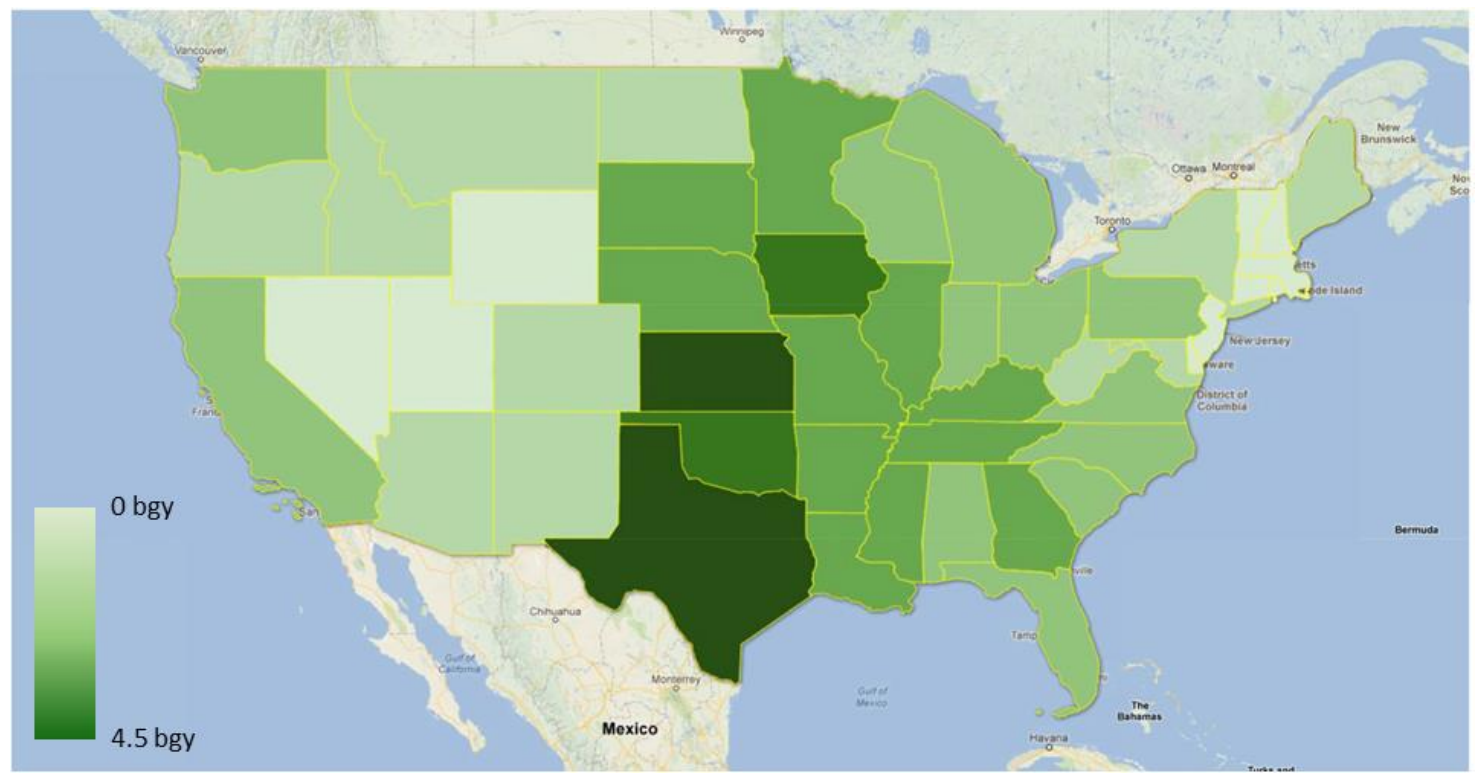

Figure 2.3. Map of Total Projected U.S. Biofuel Production

(from KDF, state averages, based on $\$ 60 /$ dry ton - at farm gate - for the year 2022. The biofuel yields were estimated by adding an additional loss of $20 \%$ for each feedstock due to handling and storage losses, and applying a 85-gallons-per-dry-ton conversion factor.)

Radii of 25, 50, and 100 miles around a given refinery are used for the biomass availability projections. Stateaverage biomass data is used to calculate the biomass feedstock availability for a given radius. Appendix B shows the detailed data for each biomass feedstock type at each refinery location, using the above procedure.

Figure 2.4 shows a plot of the candidate Category 3 refineries (detailed data are shown in Appendix Table B.2). This plot represents a total of 63 refineries with significant predicted biofuel production potential. The refinery data are plotted from the highest net potential bio-fuel output to the lowest (bars). The cumulative biofuel production is represented by the dark line. 


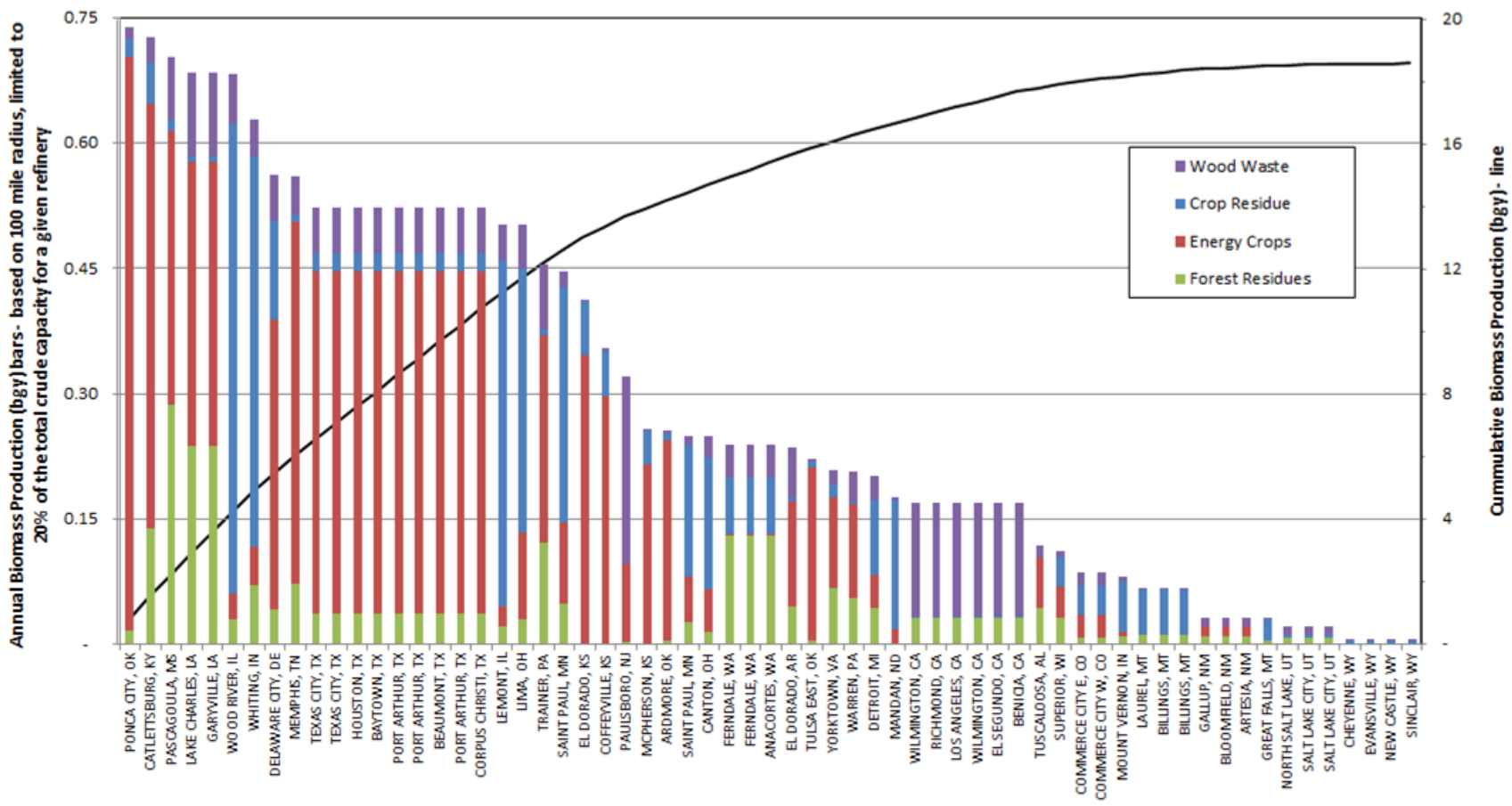

Figure 2.4. U.S. Refinery Sites with the Highest Estimated Biofuel Production volumes

Based on biomass sourcing from a 100-mile radius around each refinery site (state average data, Category 3 refineries only, down-selected based on state biomass limitations - see Appendix B) and a fast pyrolysis conversion route. The equivalent biofuel into any refinery was limited to $20 \%$ of the total crude capacity.

The methodology for generating this plot is a follows: the number of candidate (Category 3 ) refineries is estimated by first calculating the number of a given radii that could fit a given state's area. If that number is larger than the refinery capacity for a given state, the number of candidate refineries is capped at the number of available refineries. However, in a number of cases, the number of available refineries is larger than the maximum determined from the biomass calculation (see highlighted values in Appendix Table B.1). For those instances the candidate refineries are down selected based on the extent of hydrotreating capability (i.e. preference to Category 3D) and refinery capacity. Appendix Tables B. 2 and B. 3 show the individual Category 3 refineries that are included in the candidate set, and excluded based on the biomass limits and corresponding down selection.

For each of the individual refinery cases the biomass feedstock mass values are converted into finished fuel displacement volumes assuming a biomass conversion pathway that produces a wide-boiling point and using the conversion factors described in Section 2.1. Once the fuel displacement volumes are estimated they are converted to corresponding crude volumes for the given refinery. Here, a typical refinery gain (finished fuels compared to inlet crude) of $7 \%$ was used ${ }^{[7]}{ }^{[8]}$ Next, the calculated displacement by bio-oil is not allowed to exceed $20 \%$ of the inlet crude volume. This cap is chosen somewhat arbitrarily at this point and will ultimately be driven by policy, institutional, or practically factors. Note that some initial studies on co-processing fast pyrolysis oil with petroleum-derived streams show favorable fluidized catalytic cracking conversion performance with a blend of $20 \%$ pyrolysis oil ${ }^{[8]}$ 
The data in Figure 2.4 show that for a 100-mile radius around the candidate Category 3 refineries, and a limit of no more than a $20 \%$ offset of current crude volumes, a cumulative biofuel production of nearly 19 bgy is predicted. If the data set is limited to the top 44 refineries in Figure 2.4 a total biofuel production of around 18 bgy is estimated. These estimates are lower than the EISA-RFS advanced biofuels target of 21 bgy, but are well within the and acceptable range considering the accuracy of the projections, and the fact that cellulosic ethanol is also expected to contribute to the advanced biofuel target level.

The individual bars in Figure 2.4 are broken down for each primary biomass source. This breakdown shows that the energy crop availability in 2022 will have a large effect on most of the refineries shown. For those refineries in Texas, Kansas, and Oklahoma, the predominant feedstock class is energy crops, and one can nearly neglect the other feedstock classes without a significant loss of the capacity. Wood waste is the predominant biomass feedstock for the refineries in California. Approximately half the projected production of bio oil for the refineries in the state of Washington is provided by forest resources, followed by crop residue and wood waste. Forest resources are also meaningful for the refineries in Mississippi and Louisiana, where they account for at least a third of the estimated biofuel production. Finally, as expected, those refineries in the Midwestern states show crop residues as the dominant class of feedstock. Still, of the top 44 refineries shown in Figure 2.4, only 11 show crop residue as the predominant feedstock class.

The key assumptions feeding the comparison have their own associated sensitivities to the total projections. The radius around each refinery in Figure 2.4 is set at 100 miles. If a 25 -mile radius is chosen the total predicted biofuels production is only 2 bgy, and 7 bgy for a 50 -mile radius (see Appendix B). If a $10 \%$ constraint on crude inlet volume displacement is applied, the 25 and 50-mile feedstock radius predictions are nearly unchanged. However, the 100-mile prediction is reduced to $14 \mathrm{bgy}$. If the constraint is increased to $30 \%$, the 25 and 50-mile predictions are again unchanged, but the 100-mile prediction increases to 21 bgy.

This coarse sensitivity study suggests that a significant biomass feedstock area will be required in order to achieve the EISA goals, possibly equal to or greater than 100 miles in radius around a given refinery. Further, while the $20 \%$ inlet crude offset constraint assumed for each refinery is somewhat arbitrary, it appears to be representative of what will need to be considered for the candidate refineries. Future refinements to this analysis should include future improvements to the biomass feedstock supply system. For example, the uniform-format feedstock supply system and the least cost formulation research conducted by the Idaho National Laboratory ${ }^{[9]}$ 


\subsection{IMPACT OF BIO-BASED INTERMEDIATES ON REFINERY OPERATIONS}

\subsection{Bio-oil Intermediates}

There are a number of options for converting biomass to liquid fuels or precursors with potential for refinery finishing. Biomass fermented to ethanol, or liquid fuels from gasification and syngas conversion via FischerTropsch, Methanol-to-Gasoline, or mixed alcohols, impact a refinery downstream at fuel blending. Direct liquefaction, certain syngas-based routes, metabolic and catalytic conversion of sugars, and algal processing routes all have the potential to produce bio-oil intermediates (as opposed to blendstocks) that could be candidates for insertion into a current refinery process.

The bio-intermediate candidates will have varying levels of oxygen. The maximum allowable oxygen content and impacts of different oxygenates species are not yet known, but certain routes will need some level of deoxygenation before they can be considered for refinery insertion ${ }^{[10]}{ }^{[11]}$ Fast pyrolysis oil, for example, will need significant oxygen reduction prior to refinery processing, whereas algae derived oil may need none. Typical means for oxygen removal are hydrotreating and zeolite cracking. Even still, high fractions of partially deoxygenated bio-oils are not recommended in current refinery FCC operations by any of the co-processing studies cited here, as there is expected to be substantial losses to coke and dry gas ${ }^{[10]}{ }^{[12]}$

Little data exist regarding potential bio-oil intermediate qualities. Table 3.1 compares some of the available data on hydrotreated fast pyrolysis oil intermediates against an example petroleum-based crude oil for various boiling fractions.

Table 3.1. Comparison of Petroleum- and Bio-based Crude Compositions ${ }^{[13]}$ [14] [15] $^{[1}$

\begin{tabular}{|c|c|c|c|c|c|c|c|c|c|c|c|c|}
\hline & \multicolumn{3}{|c|}{ Light Naphtha Cut } & \multicolumn{3}{|c|}{ Heavy Naphtha Cut } & \multicolumn{3}{|c|}{ Kerosene Cut } & \multicolumn{3}{|c|}{ Diesel Cut } \\
\hline & $\begin{array}{l}15- \\
75^{\circ} \mathrm{C}\end{array}$ & C5 - & $71^{\circ} \mathrm{C}$ & $\begin{array}{c}75- \\
165^{\circ} \mathrm{C}\end{array}$ & $71-1$ & $182^{\circ} \mathrm{C}$ & $\begin{array}{c}165- \\
250^{\circ} \mathrm{C}\end{array}$ & $182-$ & $260^{\circ} \mathrm{C}$ & $\begin{array}{c}250- \\
345^{\circ} \mathrm{C}\end{array}$ & $260-$ & $338^{\circ} \mathrm{C}$ \\
\hline & \multirow{2}{*}{$\begin{array}{l}\text { North } \\
\text { Slope } \\
\text { Crude }\end{array}$} & \multicolumn{2}{|c|}{$\begin{array}{l}\text { Hydrotreated } \\
\text { Pyrolysis Oil } \\
\text { from Biomass }\end{array}$} & \multirow[t]{2}{*}{$\begin{array}{l}\text { North } \\
\text { Slope } \\
\text { Crude }\end{array}$} & \multicolumn{2}{|c|}{$\begin{array}{l}\text { Hydrotreated } \\
\text { Pyrolysis Oil } \\
\text { from Biomass }\end{array}$} & \multirow[t]{2}{*}{$\begin{array}{l}\text { North } \\
\text { Slope } \\
\text { Crude }\end{array}$} & \multicolumn{2}{|c|}{$\begin{array}{l}\text { Hydrotreated } \\
\text { Pyrolysis Oil } \\
\text { from Biomass }\end{array}$} & \multirow{2}{*}{$\begin{array}{l}\text { North } \\
\text { Slope } \\
\text { Crude }\end{array}$} & \multicolumn{2}{|c|}{$\begin{array}{l}\text { Hydrotreated } \\
\text { Pyrolysis Oil } \\
\text { from Biomass }\end{array}$} \\
\hline & & $8.2 \% 0$ & $0.4 \% 0$ & & $8.2 \% 0$ & $0.4 \% 0$ & & $8.2 \% 0$ & $0.4 \% 0$ & & $8.2 \% 0$ & $0.4 \% 0$ \\
\hline Wt\% Yield & 5 & 5 & 14 & 13 & 20 & 30 & 12 & 19 & 22 & 17 & 17 & 21 \\
\hline \multicolumn{13}{|l|}{ Aliphatics (vol\%) } \\
\hline Paraffins & \multirow{2}{*}{86} & 7.9 & 28.3 & \multirow{2}{*}{46} & 15.4 & 5.9 & \multirow{2}{*}{37} & \multirow{3}{*}{10} & \multirow{3}{*}{33} & 3 & & \\
\hline Isoparaffins & & 32.8 & 14.9 & & 26.8 & 38.8 & & & & 30 & & \\
\hline Naphthenes & 13 & 31.8 & 51.3 & 39 & 46 & 20.3 & 44 & & & 38 & & \\
\hline Aromatics (vol\%) & & 10.9 & 5.6 & 14 & 11.8 & 27 & 15 & 52 & 38 & 31 & & \\
\hline Olefins (vol\%) & & 16.7 & 0.07 & & 0.01 & 8.3 & & & & & & \\
\hline Benzene (vol\%) & & 0.3 & 0.5 & & 0.4 & 0.8 & & & & & & \\
\hline Unidentified & & & & & & & & 30 & 25 & & & \\
\hline TOTAL & 99 & 100 & 101 & 99 & 100 & 101 & 96 & 92 & 96 & 99 & & \\
\hline $\mathrm{H} / \mathrm{C}$ molar ratio & 2.23 & 1.96 & 2.04 & 1.96 & 1.88 & 1.85 & 1.89 & 1.69 & 1.7 & 1.75 & 1.56 & 1.55 \\
\hline Acidity* & 0.001 & 102 & ND & \begin{tabular}{|l|}
0.009 \\
\end{tabular} & 123 & ND & 0.03 & 67 & ND & 0.098 & 20 & 0.1 \\
\hline RON & 71 & 79 & 64 & 64 & 71 & 88 & & & & & & \\
\hline
\end{tabular}

*Crude acidity is by Total Acid Number, Bio-oil acidity is by Carboxylic Acid Number 
Distillation fractions of a crude source are typically used to understand the gross characteristics of that source (see Appendix C). However, with bio-oil intermediates the distillation fractions, or cuts, can be misleading due to the potential large differences in molecular composition. Here differences in the molecular compositions exist between the hydrotreated pyrolysis oils compared to a petroleum-based source. The amount of oxygen in the hydrotreated pyrolysis oils (shown as either 0.4 or $8.2 \mathrm{wt} \%$ oxygen) also shows a significant impact on the species composition. Limited data are available for hydrotreated pyrolysis oil boiling in the diesel range. However, the molar hydrogen to carbon ratio suggests that the majority of the compounds are a mix of aromatic and naphthenic types. Further, the higher oxygen content in the pyrolysis oils corresponded higher levels of organic acids.

Overall, regardless of oxygen content, Table 3.1 shows a higher level of aromatic compounds in the lighter cuts of the pyrolysis oils compared to the petroleum-based crude source. The aromatic level in the diesel cut may be incompatible with diesel fuel specifications unless additional or more severe hydrotreating is applied.

Therefore, cracking via FCC or a hydrocracker may be a more attractive means of converting the aromatics to an acceptable blend form. Recent reviews indicate more attention is being paid to hydroprocessing of bio-oils, however, little data exist regarding the detailed characteristics of the distillation fractions of these bio-based liquefaction oils ${ }^{[16]}[17]$

\subsection{Estimates of Natural Gas for Hydrotreating Bio-oils}

Pyrolysis oil is an example of a bio-oil requiring considerable hydrotreating in order to produce a hydrocarbon. Estimates for pyrolysis oil hydrogen consumption suggest that approximately a third of the biomass source would have to be consumed if the hydrotreating hydrogen were provided completely from the biomass source itself ${ }^{[18]}$ As a result, natural gas is likely to be the most economic source of hydrogen for pyrolysis oil hydrotreating as long as the reduction in green-house-gas emissions are greater than $50 \%$ (to be considered an Advance Fuel) or $60 \%$ (to be considered a Cellulosic Fuel). Figure 3.1 shows the estimated high and low natural gas consumption for converting raw pyrolysis oil into finished fuels. The current natural gas consumption for U.S. refineries is also included in the plot ${ }^{[19]}$

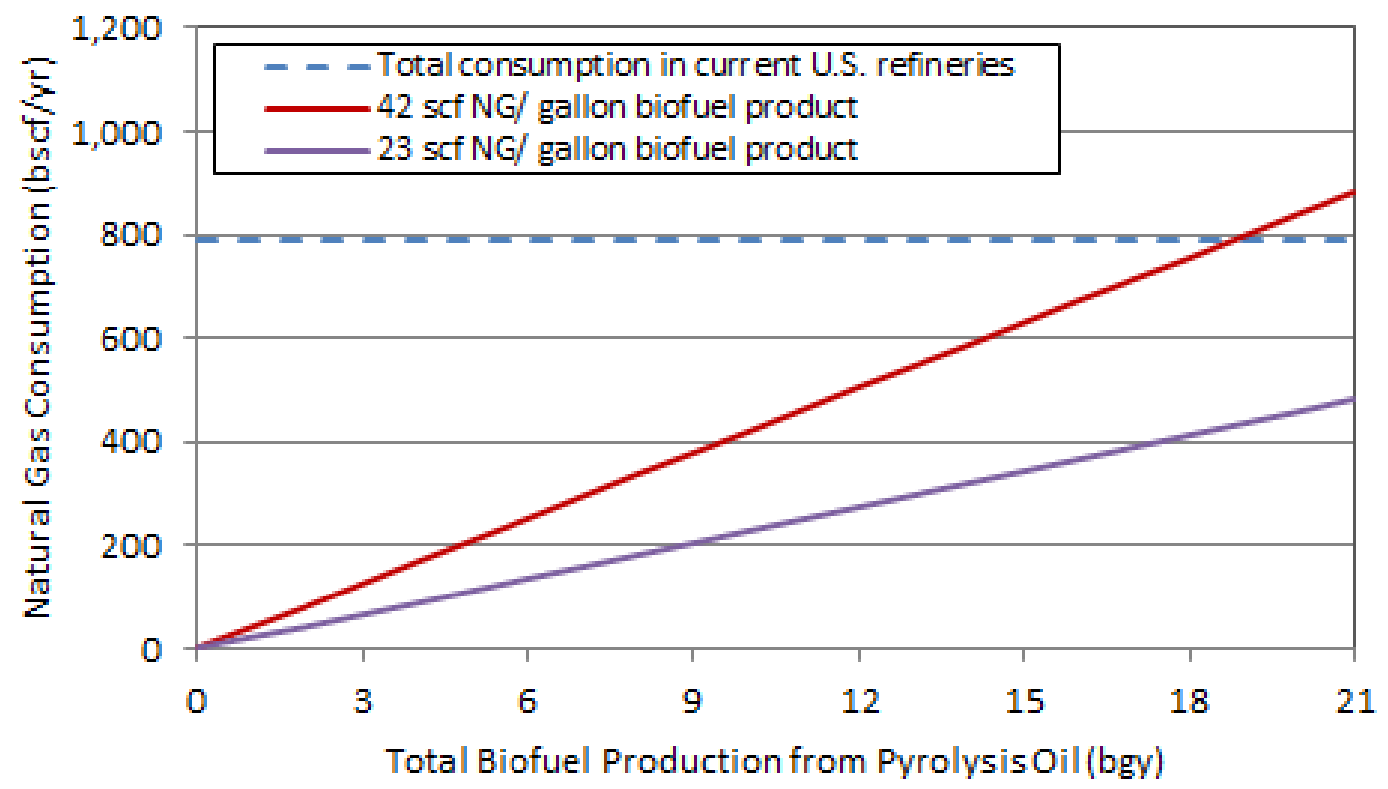

Figure 3.1. Estimates of Natural Gas Demand for Hydrotreating Pyrolysis Oils ${ }^{[18]}[19]$ 
At the upper end of the natural gas usage assuming the full advanced biofuel target ( 21 bgy) supplied from raw pyrolysis oil, Figure 3.1 shows the corresponding natural gas demand to be nearly equal to current U.S. refinery demands. Lower pyrolysis oil contributions and/or lower natural gas usage would lessen the overall natural gas consumption. Nevertheless, this suggests that at least $50 \%$ more of the current U.S. refinery demand for natural gas will be necessary in any significant raw pyrolysis oil scenario. Indeed, this requirement will be significant against the current refinery capacities for hydrogen generation hydrotreating, such that the available equipment/capacity may not be adequate. If so, additional hydrotreating capacity could be considered inside or outside of the refinery boundary, perhaps at more centralized treatment and distribution facilities.

\subsection{Co-processing of Bio-oil Intermediates in Refinery Units}

Few published studies exist regarding the co-processing of bio-oils with conventional petroleum sources at various insertion points. Several available studies characterize products of co-processing biomass-derived fast

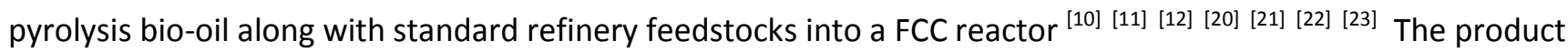
distributions from some of these studies are plotted in Figure 3.2. Here, co-processing with upto $20 \%$ bio-oil showes final product distributions close to those from running straight refinery feedstock (SGO or VGO). Conversely, pure bio-oil (HDO) produced larger amounts of dry-gas and coke. A separate study using ${ }^{14} \mathrm{C}$ radiocarbon methods showed that bio-carbon preferentially concentrates at the coke and gaseous products during co-processing, with the conclusion that hydrogen transfer from the refinery feedstock to the bio-oil during co-processing helps mitigate overall formation ${ }^{[12]}$

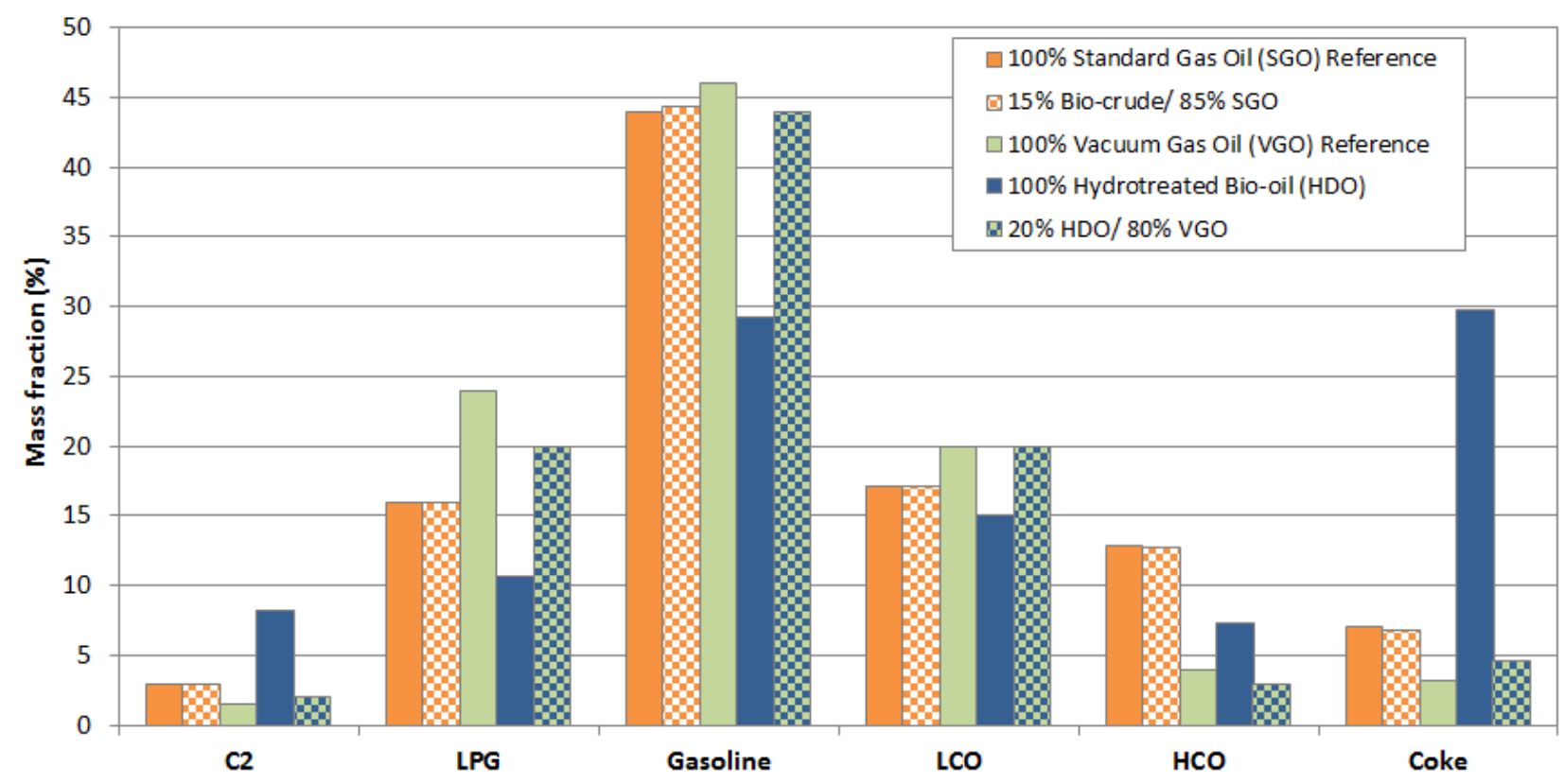

Figure 3.2. Published Data of FCC Product Distributions with and without Bio-Oil Co-processing (SGO testing by Agblevor ${ }^{[10]}$ and VGO/HDO testing by Fogassy ${ }^{[11]}$

The molecular compositions of the data represented in Figure 3.2 are limited. The VGO/ HDO testing results by Fogassy included some comparisons of aliphatic and aromatic contents of the produced products, which 
were similar between the pure and mixed cases. The alkylbenzene content of the HDO blend was higher (approximately $30 \mathrm{wt} \%$ versus $21 \mathrm{wt} \%$ ), as was the toluene content ( $3 \mathrm{wt} \%$ versus $1.5 \mathrm{wt} \%)^{[11]}$

Catalyst selection is a critical research need, as molecules from bio-oil seem to be less compatible with typical FCC catalysts or additives when residual oxygen is significant. Certain catalyst additives may be better than others (e.g. ZSM-5 favors coking, etc). Studies done by Fogassy, Mercader, and Graca demonstrated higher levels of substituted phenols in the gasoline and LCO fraction of the product mainly due to ineffective coversion by typical FCC catalysts ${ }^{[8] ~[20] ~[22] ~ I t ~ i s ~ i m p o r t a n t ~ t o ~ n o t e ~ t h a t ~ t h e ~ a v a i l a b l e ~ p u b l i s h e d ~ t e s t ~ d a t a ~ f o r ~}$ pyrolysis oil co-processing was generated in bench-scale test systems, mostly at universities.

The National Advance Biofuels Consortium (NABC) has published data regarding their processing pathways. Hydrocarbon produced via the catalysis of sugars, hydrothermal liquefaction, hydropyrolysis, and fermentation of sugars are categorized based on boiling point and density. The naphtha, distillate and heavy cuts from these intermediates are all considered able to be processed in hydrotreaters, hydrocracker or catalytic pyrolysis units. No data are reported for oxygen content ${ }^{[24]}$

The 2012 Bio-Oil Stabilization and Commoditization solicitation funding opportunity is aimed at better understanding the impact of bio-oil intermediate processing in a conventional refinery. Awardees from this solicitation will help address the lack of co-processing data ${ }^{[25]}$

\subsection{The Refiner's Perspective on New Feedstocks - General}

Refiners are accountable to a broad range of constituents including shareholders, regulators, neighbors, vehicle manufacturers, and end users of their product. To satisfy all of these parties refinery operators focus on the following key areas:

Safety - Operating refineries in a manner that is safe for operating staff, neighbors, and the environment is absolutely essential. Each day an individual refinery processes hundreds of thousands of barrels of flammable materials heated to high temperatures and pressures. The use of hydrogen, electricity, steam and water in refining operations presents their own set of hazards and ongoing challenges. By-products such as process water, ammonia, and hydrogen sulfide must also be safely handled.

Reliability - The refinery must continuously process crude oils to make a defined slate of products within a narrow set of product specifications. Unexpected interruptions or shutdowns of even single process units can cripple a refinery for weeks or months and create risks for staff, neighbors and customers, and affects refiner's ability to meet seasonal demand swings for various fuels and products.

Predictability - Refiners must also be able to make the amount of products that meet market demands with product performance characteristics that meet consumer needs, and be able to predict how changes in feedstocks will affect their products and operating performance.

Profitability - Substantial investments are required to build and operate refineries with corresponding expectations on refinery management to utilize the equipment in a manner that maximizes the return to investors. Profitability of refineries regularly changes in response to prices of crude oils, intermediate products and end products in the market and refiners need to be confident that they can vary operating conditions with new feedstocks in a manner that continues to support good profitability and to minimize demand for additional capital equipment. New feedstocks can also carry additional risks of unexpected and costly maintenance requirements, premature catalyst deactivation, or accelerated corrosion. 
Refiners regularly evaluate opportunities to change the feedstocks responding to price and availability of various crude oils and to the abilities to their refineries to convert various feedstocks into the slate of products (e.g. gasoline, diesel, jet fuel, etc.) to meet anticipated or contractual demands at a particular time of year. They utilize their prior experience along with a suite of analytical and computational tools to allow them to make predictions of the performance of a new crude oil or blend of crude oils in their refining equipment. When a given refinery has past experience with a particular crude oil there can be very good confidence in predicting the ability of the given refinery to convert the crude to a slate of products (a particular mix of gasoline, diesel, jet and other products) that best delivers stable operations and high profitability within the capabilities of the refinery (including power, steam, hydrogen and other requirements as well as equipment maintenance schedules and other logistics).

When a new crude oil is being considered, a large battery of analytical tests are typically performed dividing the crude into narrow boiling range components and examining the chemical characteristics of each component to estimate its response in conversion and hydrotreating processes. These test results are then fed to computational models that allow the refiner to predict product quantities and qualities and to estimate impacts on the continuous running time of key process equipment (for instance, the impact of crude quality on catalyst lives in cracking, hydrotreating and catalytic reforming equipment). Prior experience with a feedstock is by far the best predictor of performance; chemical similarity to other prior feedstocks is a less desirable second. Refiners will rarely risk running entirely new, entirely chemically different feedstocks without performing additional process performance tests (for instance, in small scale pilot plants) that measure product quantities and allow quality testing of products while also giving indications of impact on catalyst lives, hydrogen demand and other important refinery performance measures.

\subsection{The Refiner's Perspective on Biomass-based Feedstocks}

Processing bio-based feedstocks will be new to many or most refiners. They will need to have sufficient ability to ensure that their operations can continue to be safe, reliable, predictable and profitable when processing these feedstocks. Further, different bio-based feedstocks present different risk profiles to refiners and will require differing degrees of testing and evaluation before they can be integrated into the refining system. A general rule is that the closer a bio-based feedstock is to conventional petroleum feedstocks and products, the easier the path will be to integrating the feedstock into refineries. Table 3.2 shows the potential biomassbased intermediates that could enter a refinery along with the potential insertion points and likely relative risk ranking for a given refinery. 
Table 3.2. Candidate Biomass-Based Feedstocks, Likely Refinery Insertion Points and Associated Risk Factors

\begin{tabular}{|c|c|c|c|}
\hline $\begin{array}{l}\text { Refiner's } \\
\text { Risk } \\
\text { Category }\end{array}$ & Type of Bio-oil Intermediate & $\begin{array}{l}\text { Likely Refinery } \\
\text { Insertion } \\
\text { Point(s) }\end{array}$ & Refinery Challenges \\
\hline Lowest & $\begin{array}{l}\text { Intermediates requiring the } \\
\text { least amount of refinery } \\
\text { processing (e.g. ethanol, } \\
\text { butanol, renewable diesel } \\
\text { blendstocks, single molecule } \\
\text { hydrocarbons }\end{array}$ & Blending units & $\begin{array}{l}\text { - Blending, product performance and distribution of } \\
\text { products that include the bio-component. } \\
\text { - Evaluating and managing potential stability, } \\
\text { toxicity and environmental issues from the new } \\
\text { fuel. }\end{array}$ \\
\hline Medium & $\begin{array}{l}\text { Intermediates requiring only } \\
\text { minor treating for } \\
\text { conversion/upgrading/cracking } \\
\text { to be acceptable blending } \\
\text { stocks (e.g. triglycerides, } \\
\text { aquatic feedstock-based } \\
\text { hydrothermal liquefaction oils, } \\
\text { some catalytic fast pyrolysis } \\
\text { oils, catalytically derived sugar } \\
\text { oils) }\end{array}$ & $\begin{array}{l}\text { Hydrotreating } \\
\text { followed by } \\
\text { blending }\end{array}$ & $\begin{array}{l}\text { Challenges identified above, plus: } \\
\text { - Understanding process performance on new feeds } \\
\text { and blends with petroleum-based feeds. } \\
\text { - Enabling larger fractions of bio-oil blending stocks } \\
\text { while still meeting product specifications. } \\
\text { - Providing sufficient hydrogen to meet } \\
\text { hydrotreating demands (for reducing oxygen or } \\
\text { aromatic contents). }\end{array}$ \\
\hline Highest & $\begin{array}{l}\text { Intermediates requiring boiling } \\
\text { range and composition } \\
\text { changes to be converted to } \\
\text { acceptable gasoline, diesel and } \\
\text { jet fuel blending stocks (e.g. } \\
\text { fast pyrolysis oils, terrestrial } \\
\text { feedstock-based hydrothermal } \\
\text { liquefaction oils, some } \\
\text { catalytically derived pyrolysis } \\
\text { oils). }\end{array}$ & $\begin{array}{l}\text { Off-site or } \\
\text { dedicated on- } \\
\text { site } \\
\text { hydrotreating } \\
\text { followed by FCC, } \\
\text { or } \\
\text { hydrocracking }\end{array}$ & $\begin{array}{l}\text { Challenges identified above, plus: } \\
\text { - Understanding the impact of bio-oils on all } \\
\text { refinery processes. } \\
\text { - Meeting product quantity and quality needs with } \\
\text { feedstocks with less data on conversion behavior. }\end{array}$ \\
\hline
\end{tabular}

The most suitable bio-oils for most refiners will be those that require minimum processing, i.e. those having boiling ranges and compositions that best match the characteristics of existing gasoline, diesel and jet fuel blending stocks. These can in principle be handled by all refineries that market distillate products. These feedstocks may be capable of being directly blended into conventional petroleum product streams, thus presenting the lowest overall risk to refinery performance. Even with this easiest integration case, refiners still need to manage blending and product delivery and performance challenges and with the addition of any new component carries additional toxicity, stability, corrosivity and environmental management risks that must be thoroughly evaluated and managed.

\section{Lowest Risk to Refiners}

Single molecule biofuels with well-defined and controlled properties are the easiest type of fuel to handle. Ethanol in gasoline is perhaps the easiest and most experienced example of bio-based fuel blending. But even with its manageable blending (e.g. a relatively wide miscibility range and manageable volatility) and product properties (acceptable octane value), blending ethanol creates a host of well-known issues to manage such as limits to acceptable blend compositions, required changes in product delivery and distribution systems, 
impacts on susceptibility of the fuel to absorbing water, limits to the vehicles capable of using the blends affects the choice of vehicles capable of using the blends, end performance changes of the fuel in vehicles, and the need to develop new environmental management approaches in the event of accidental releases or spills. Farnesene, derived microbially from sugar, is an example of a single molecule hydrocarbon, with fewer blending issues than oxygenated compounds, but would likely need hydrotreating first. The advantage of these types of biofuels is that their principle challenges lie downstream of major processing equipment, allowing the rest of the refinery units to run on petroleum-based feedstocks predictably and reliably.

\section{Medium Risk to Refiners}

The next most desirable bio-oils for most refiners are those that match conventional products well in boiling range but may require additional treatment to lower impurity levels and change composition to better fit into blends with conventional products. An example of this type of oil is a near completely deoxygenated bio-oil. Using this type of bio-oil moves the refinery challenges one further step upstream compared to well defined, finished blendstocks such as ethanol, biobutanol or similar molecules. Refiners will need to have confidence in the way in which these feedstocks must be processed to create viable blending components and be able to predict process unit performance when these components are blended into others derived from crude oil. Refiners will also need to be able to meet product specifications using these components, fully understand the ability of oxygenates other inorganic species to migrate throughout the refinery together with the identity of species present under refinery conditions, and assure good engine performance on the blends. This will likely require fairly extensive process tests, blending studies, long term catalyst exposure/accumulation studies, and engine performance tests followed by the creation of computational predictive tools that enable the refiner to understand and reliably predict how the new feedstocks will affect process performance and product qualities. Such efforts could also be needed in support of Renewable Identification Numbers for fuels containing bioderived components.

\section{Highest Risk to Refiners}

The most difficult bio-based feedstocks to integrate into the refining systems are those that will require combinations of conversion and hydrotreating to convert them into products capable of being blended with conventional petroleum products. These feedstocks will require refineries with conversion and hydrotreating capacities and can potentially impact the entire refinery operation. For these feedstocks detailed testing of conversion and hydrotreating unit performance will be needed. Product quantities and qualities can be impacted, and process unit performances, catalyst life and other key operating factors will likely be affected and must be measured. The ability to vary product slates would be most at risk for such bio-oil feeds.

Predictive tools will need to be developed using these feed components for a broad range of process units and conditions, and for predicting and testing product blend properties and performance.

\section{Refinery Operating Balance}

These types of feedstocks will also likely affect critical refining operating balances. Refiners need to balance refineries for fuel demand (attempting to match produced gas with refinery fuel and hydrogen production needs), to reduce utility demands (e.g. electricity, steam, cooling water, hydrogen), and to meet other refinery operating limits and constraints. The entire refinery operating plan can be affected. Possibly of greatest concern to many refiners will be hydrogen demand as many bio-oils have very high oxygen and/or aromatics contents. New feedstocks also pose additional risks beyond predictability of process and product performance, including corrosion (a particular concern for high-oxygen-content feeds), erosion, toxicity, trace component impacts and environmental management concerns. A more specific list of additional refinery 
concerns is given in Appendix $C$. These concerns and the ones listed above frame up an overall challenge in the desire to have access to maximum refining capability from the bio-fuels production and the desire to minimize bio-fuels impacts on the overall refinery from the point of view of the refiner.

\section{Positive Effects}

Accompanying the risk of downsides are also some potential upsides. It is conceivable that the presence of bio-derived feeds could shift refinery balances in favor of components that improve refining flexibility, reduce blending demands, or create products that can be utilized for higher values than the traditional product mix (e.g. chemicals feedstocks, lube oil components). As with the prediction of downsides, these will require considerable testing of process performance of bio-derived oils (including longer term impacts such as catalyst fouling) and the development of predictive tools to allow refiners to understand the full product slate impacts of the changes. It may also be possible that refiners will be able to capture additional value from the incorporation of bio-derived oils through gaining renewable fuel credits or other regulatory-origin values from the use of these feeds. Quantifying these values and balancing these against potentially higher processing costs will require considerable performance data and reliable predictive capabilities. 


\subsection{CONCLUSIONS AND RECOMMENDATIONS}

The key conclusions from this analysis are:

- Most refineries have the necessary conversion units. There are 149 U.S. refineries listing in the current EIA database. Of those refineries 106 have some conversion capacity (cracking or hydrocracking) and some degree of hydrotreating capacity. This subset of refineries is deemed the most likely for any degree of bio-oil processing, beyond blending, and represents $90 \%$ of the U.S. refining capacity on a volume basis.

- Sufficient refining capacity available based on first assessment. At a high level, geographical distribution of anticipated bio-fuels production sites and existing refinery capabilities suggests that overall the objectives for advanced biofuels of federal EISA and the RFS can be met by a subset of the candidate refineries, potentially as few as 50. A 100-mile radius around a given refinery site appears to be near the distance required to assure an adequate supply of biomass feedstock consistent with a $20 \%$ (maximum) offset of existing petroleum feeds to those refineries. This assessment assumes only a minor contribution from cellulosic ethanol. If a majority of the advanced biofuel target was met with cellulosic ethanol, the front-end refinery demands would be much lower. However, the impact of biointermediate selection on fuel products (gasoline, diesel, jet) must also be considered.

- The US Gulf Coast appears to be an important region. The regional matching study also revealed the relative importance of the U.S. Gulf Coast where a significant portion of bio-oil refining may need to occur to match adequate refining capacity. Hydrotreating capacity and hydrogen production limits may well be exceeded in this region and substantial refining investments may need to occur to support the federal biofuels objectives. The examination of bio-oil insertion from a refiner's perspective reveals a broad range of challenges from processing performance to ability to produce adequate quantities and qualities of products, to product performance issues that will require considerable more effort to further evaluate and resolve. The degree of refinery challenges greatly depends on the type of bio-oil to be inserted, with those demanding the least refinery processing (e.g. ethanol, single molecule hydrocarbons) creating significantly reduced challenges relative to those demanding conversion and hydrotreating (e.g. pyrolysis oils). Extensive process and product testing programs will be needed to support refinery insertion for all oils, especially those whose composition differ the most from conventional petroleum oils. Significant analytical resources are necessary to facilitate the introduction of bio-oils the unique upgrading and blending models used by refiners.

- Too little co-processing testing data is available. Published data around processing bio-oils in conventional refinery processes is relatively sparse. This should be mitigated somewhat by results from the 2012 Bio-Oil Stabilization and Commoditization solicitation and publications from the NABC. However, industrial entities within these programs may be reluctant to publish. Existing data suggest that bio-oils may be co-processed with conventional petroleum oils but considerably more publically available processing studies will be needed to provide adequate information to refiners to support broad insertion. These data can then be used to determine the economic trade-off between complete conversion of biomass to biofuels in a stand-alone plant versus partial conversion at the biofuels plant coupled with fuel finishing in a conventional refinery.

- Standards needed for biofuel blendstocks and bio-oil intermediates. The eventual resolution of these refinery integration challenges will lie in having adequate experience with the processing of various 
bio-based feedstocks in conventional refinery processes to give refiners an equivalent level of predictability of process performance as they currently have with petroleum-based feedstocks. This suggests the importance of developing process tests for the various types of bio-based feedstocks, alone and in combination with petroleum-based feeds, in all of the expected key process steps (particularly FCC, hydrocracking and jet and diesel hydrotreating). Note that the international community (IEA Bioenergy, Task 34) is actively engaged in standardizing the ways in which bio-oil properties are measured. An ASTM standard does exist for the use of fast pyrolysis oil in commercial boilers.

The following recommendations are offered:

1) Enhance the current resource assessment further. a more detailed study of biomass availability and refining capabilities for the key regions identified, primarily the U.S. Gulf Coast region will address gaps in the current analysis. Future assessments should be performed with the actual feedstock availability at the county level and incorporate non-terrestrial feedstocks matched to conversion yields and total processing costs. Incorporation of new data should also be considered in either a centralized or distributed model with densification, formatting, and stabilization considerations, such as that from the INL Uniform Format Feedstock Supply System analysis.

2) Improve the chemical understanding of intermediates and fuels and their properties. Bio-oils are complex mixtures with limited characterization. Future analysis should develop the capability for analyzing and understanding the molecular compositions of feedstocks and resulting products and how they affect refinery operations and final product performance. Incorporation of key refinery blending factors into subsequent refinery insertion point research and development (Pour Point, Boiling Point, Cloud Point, API, Cetane Index, etc.) and molecular composition information will allow better prediction of bio-based feedstock compatibility with existing refinery process streams.

3) Enable a partnership between refiners, biofuel producers, and technology developers. Responding to the concerns expressed in the conclusions may be best accomplished by creating a strong collaboration between the refining industry and the national programs that are working in the field of biomass research. As such, it is recommended that in order to identify priorities and opportunities for filling critical knowledge and experience gaps and directing investments in a manner that best supports biofuels objectives, to 1) coordinate a DOE-sponsored workshop with bio-based feedstock producers, refiners, conversion technology experts, the NABC and the DOE, to develop detailed R\&D recommendations for a refinery insertion program, 2) establish a formal on-going collaboration between DOE and industrial participants to assure the correct focus on key issues and technology gaps, potentially engaging the AFPM (American Fuel \& Petrochemical Manufacturers) as part of that collaboration. 


\subsection{REFERENCES}

[1] NABC, 2012, "A Refiner's Perspective on Advanced Fuels" National Advanced Biofuels Consortium, March 30,2012 http://www.nabcprojects.org/pdfs/refiner_perspective_advanced_biofuels.pdf

[2] Energy Independence and Security Act, http://www.afdc.energy.gov/laws/law/US/390

[3] Knowledge Discovery Framework, https://www.bioenergykdf.net/

[4] U.S. Billion Ton Update - Biomass Supply for a Bioenergy and Bioproducts Industry, Oak Ridge National Laboratory, for the U.S. DOE under contract DE-AC05-00OR22725, August 2011. http://www1.eere.energy.gov/biomass/pdfs/billion ton update.pdf

[5] Arbogast, S. et al, 2012, "Advance Bio-Fuels from Pyrolysis Oil: The Impact of Economies of Scale and Use of Existing Logistic and Processing Capabilities, Fuel Processing Technology, 104 (2012) p 121-127

[6] ElA refinery data as of January 1, 2011, http://www.eia.gov/petroleum/data.cfm\#refining/refcap11.xls

[7] U.S. Energy Information Administration, Petroleum Supply Annual 2011, Volume 1, Table 23

[8] de Miguel Mercader, F., et al., Production of advanced biofuels: Co-processing of upgraded pyrolysis oil in standard refinery units. Applied Catalysis B: Environmental, 2010. 96(1-2): p. 57-66.

[9] Idaho National Laboratory, 2009, Uniform-Format Feedstock Supply System Reports https://inlportal.inl.gov/portal/server.pt?open=512\&objID=421\&PagelD=5806\&cached=true\&mode=2 \&userlD=1829

[10] Agblevor, F.A., et al., Co-processing of standard gas oil and biocrude oil to hydrocarbon fuels. Biomass and Bioenergy, 2012. 45: p. 130-137.

[11] Fogassy, G., et al., Biomass derived feedstock co-processing with vacuum gas oil for second-generation fuel production in FCC units. Applied Catalysis B: Environmental, 2010. 96(3-4): p. 476-485

[12] Fogassy, Gabriella, Nicolas Thiegarid, Yves Schuuramn, Claude Mirodatos, 2012 "The Fate of BioCarbon in FCC Co-Processing Products", Green Chemistry, 2012, 14 1367-

[13] Christiansen, Earl, Gina Chupka, Jan Luecke, Tricia Smurhtwaite, Teresa Alleman, Kristiian lisa, James Franz, Douglas Elliott, Robert McCormick “Biomass Fast Pyrolysis Oil Distillate Fractions” Energy \& Fuels 2011, 25, 5462-5471

[14] BP Crude Marketing, Alaska North Slope Crude Assay http://www.bp.com/extendedsectiongenericarticle.do?categoryld=16002777\& contentld=7020196

[15] Speight, James G. (2012). Crude Oil Assay Database. Knovel. Online version available at: http://www.knovel.com/web/portal/browse/display? EXT KNOVEL DISPLAY bookid=5485\&Verticall $\underline{\mathrm{D}=0}$

[16] Mortensen, P.M., J.D. Grunaldt, P.A. Jensen, K.G. Knudsen, A.D. Jensen “A Review of Catalytic Upgrading of BioOil to Engine Fuels" Applied Catalysis A: General, 2011, 407, 1-19

[17] Al-Sabawi, Mustafa, Jinwen Chen, "Hydroprocessing of Biomass-Derived Oils and Their Blends with Petroleum Feedstocks: A Review" Energy \& Fuels, 2012, 26, 5373-5399

[18] Jones, SB et al, 2009, Production of Gasoline and Diesel via Fast Pyrolysis, Hydrotreating and Hydrocracking: A Design Case. PNNL-18242

http://www.pnl.gov/main/publications/external/technical reports/pnnl-18284.pdf

[19] Energy Information Agency 2012 Annual Energy Review Table 6.1 Natural Gas Overview, 1949-2011 http://www.eia.gov/totalenergy/data/annual/showtext.cfm?t=ptb0601

[20] Fogassy, G., et al., From biomass to bio-gasoline by FCC co-processing: effect of feed composition and catalyst structure on product quality. Energy \& Environmental Science, 2011. 4(12): p. 5068 
[21] Fogassy, G., et al., Analytical techniques tailored for biomass transformation to biofuels. Environmental Progress \& Sustainable Energy, 2011: p. 1-7.

[22] Graça, I., et al., Bio-oils and FCC feedstocks co-processing: Impact of phenolic molecules on FCC hydrocarbons transformation over MFI. Fuel, 2011. 90(2): p. 467-476.

[23] Graça, I., et al., Catalytic cracking in the presence of guaiacol. Applied Catalysis B: Environmental, 2011. 101(3-4): p. 613-621.

[24] NABC 2012, "Comparing NABC Products to Petroleum Refinery Intermediates, Blend Components and Finished Fuels", National Advanced Biofuels Consortium, December 2012, http://www.nabcprojects.org/pdfs/comparing nabc products 120112.pdf

[25] DE-FOA-0000686 Bio-Oil Stabilization and Commoditization Funding Opportunity http://www1.eere.energy.gov/financing/m/solicitations detail.html?sol id=513

[26] U.S. Energy Information Administration. 2011, Table 10a. Fuel Consumed at Refineries by Pad District http://www.eia.gov/petroleum/refinerycapacity/table10.pdf 


\subsection{APPENDICES}

Page 24 
APPENDIX A. Table A.1. Detailed Summary of EIA Refinery Database (Units in thousands of barrels per stream day except for sulfur, which is in thousands of tons per dav, and hydroaen which is in thousands of MMCFD)




Table A.1. (Continued) Detailed Summary of EIA Refinery Database (Units in thousands of barrels per stream day except for sulfur, which is in thousands of tons per dav, and hydroaen which is in thousands of MMCFD)

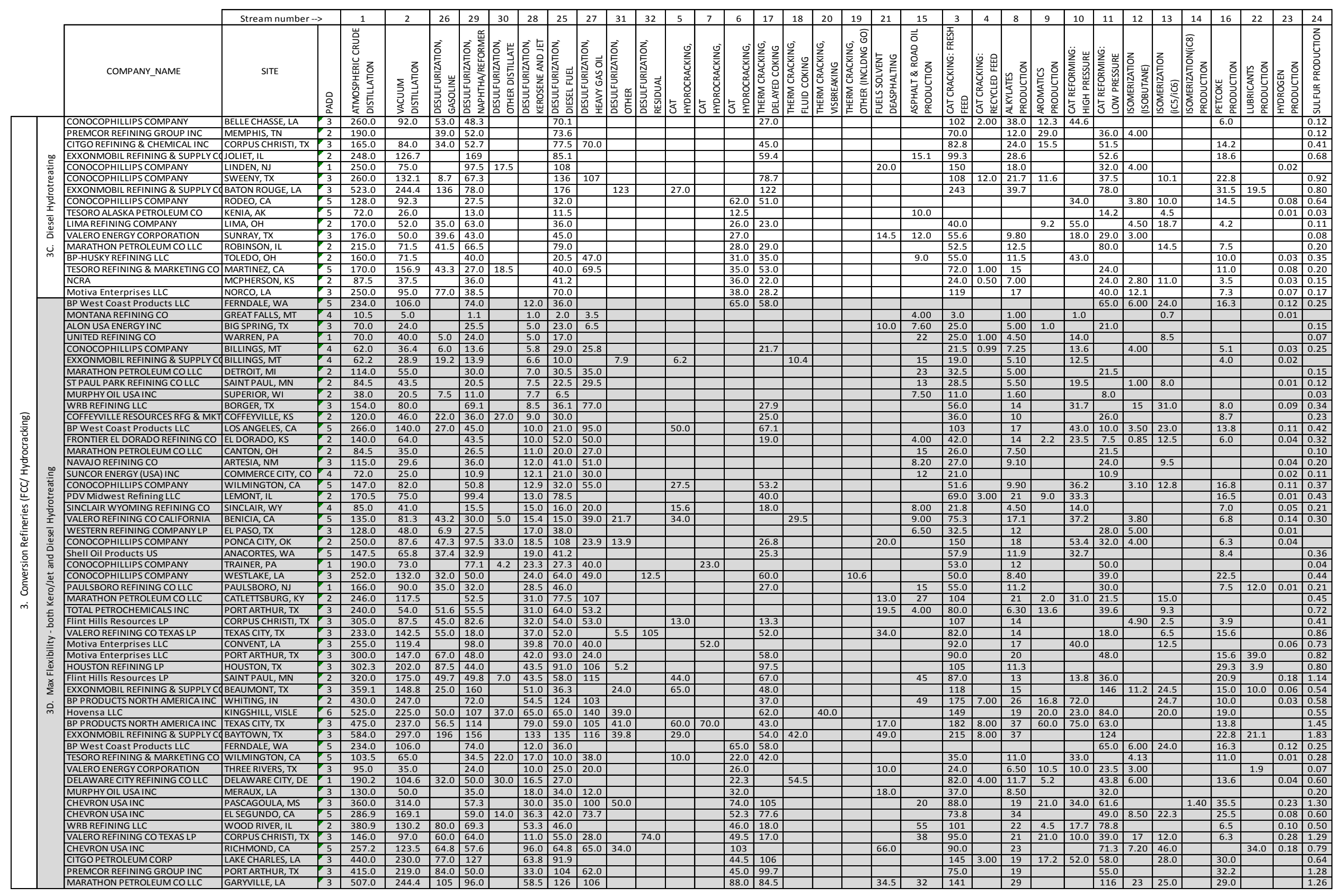


APPENDIX B. Table B.1. Summary of State-Based Biomass Feedstocks, Refinery Sites and Maximum Utilization Projections for Given Radii of Feedstocks orange highlights $=$ instances where not all refineries in a state can be utilized, yellow $=$ biofuel potential $>20 \%$ of state refinery capacity 


\begin{tabular}{|c|c|c|c|c|c|c|c|c|c|}
\hline \multirow[b]{2}{*}{ State } & \multirow[b]{2}{*}{ 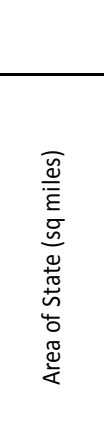 } & \multirow[b]{2}{*}{ 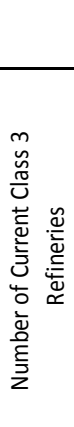 } & \multirow[b]{2}{*}{ 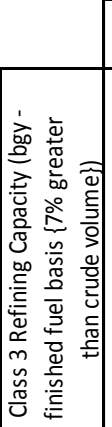 } & \multicolumn{5}{|c|}{$\begin{array}{c}\text { Biomass Feedstock Projections } \\
\text { (millions of dry tpy) }\end{array}$} & \multirow[b]{2}{*}{ 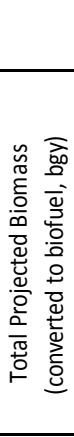 } \\
\hline & & & & 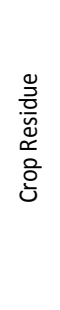 & 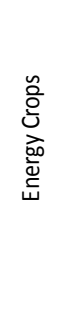 & 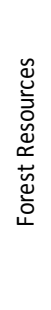 & 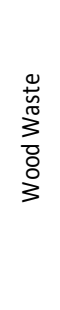 & $\begin{array}{l}\overline{\widetilde{J}} \\
\stackrel{0}{\circ}\end{array}$ & \\
\hline $\mathrm{AL}$ & 52,419 & 1 & 0.6 & 0.1 & 7.4 & 5.2 & 1.4 & 14.1 & 1.0 \\
\hline AR & 53,179 & 1 & 1.2 & 0.5 & 11.4 & 4.2 & 5.5 & 21.5 & 1.5 \\
\hline $\mathrm{CA}$ & 163,696 & 11 & 27.9 & 0.2 & 0.0 & 2.4 & 10.4 & 13.0 & 0.9 \\
\hline $\mathrm{CO}$ & 104,094 & 2 & 1.6 & 1.8 & 1.3 & 0.4 & 0.7 & 4.2 & 0.3 \\
\hline $\mathrm{DE}$ & 2,489 & 1 & 2.8 & 0.2 & 0.7 & 0.1 & 0.1 & 1.1 & 0.1 \\
\hline IL & 57,914 & 4 & 15.0 & 15.3 & 0.9 & 0.8 & 1.6 & 18.5 & 1.3 \\
\hline IN & 36,418 & 2 & 6.8 & 8.0 & 0.8 & 1.2 & 0.7 & 10.7 & 0.7 \\
\hline KS & 82,277 & 3 & 5.1 & 9.9 & 53.3 & 0.1 & 0.5 & 63.8 & 4.3 \\
\hline $\mathrm{KY}$ & 40,409 & 1 & 3.6 & 1.0 & 10.3 & 2.8 & 0.6 & 14.8 & 1.0 \\
\hline LA & 51,840 & 12 & 46.8 & 0.1 & 8.3 & 5.8 & 2.4 & 16.6 & 1.1 \\
\hline $\mathrm{Ml}$ & 96,716 & 1 & 1.7 & 4.0 & 1.8 & 2.0 & 1.3 & 9.1 & 0.6 \\
\hline $\mathrm{MN}$ & 86,939 & 2 & 6.0 & 11.5 & 3.9 & 2.0 & 0.8 & 18.2 & 1.2 \\
\hline MS & 48,430 & 1 & 5.3 & 0.3 & 7.4 & 6.5 & 1.7 & 15.9 & 1.1 \\
\hline MT & 147,042 & 4 & 2.9 & 3.8 & 0.0 & 0.7 & 0.2 & 4.7 & 0.3 \\
\hline ND & 70,700 & 1 & 0.9 & 5.9 & 0.7 & 0.0 & 0.2 & 6.8 & 0.5 \\
\hline NJ & 8,721 & 2 & 6.1 & 0.0 & 0.4 & 0.0 & 0.9 & 1.3 & 0.1 \\
\hline NM & 121,590 & 3 & 2.3 & 0.0 & 0.7 & 0.5 & 0.5 & 1.8 & 0.1 \\
\hline $\mathrm{OH}$ & 44,825 & 4 & 8.7 & 8.5 & 2.8 & 0.8 & 1.4 & 13.5 & 0.9 \\
\hline OK & 69,898 & 4 & 7.2 & 1.3 & 38.1 & 0.9 & 0.7 & 41.0 & 2.8 \\
\hline PA & 46,055 & 4 & 11.9 & 0.2 & 5.3 & 2.6 & 1.7 & 9.8 & 0.7 \\
\hline TN & 42,143 & 1 & 2.8 & 0.3 & 12.8 & 2.2 & 1.4 & 16.6 & 1.1 \\
\hline$T X$ & 268,581 & 22 & 75.2 & 2.8 & 51.4 & 4.7 & 6.8 & 65.7 & 4.5 \\
\hline UT & 84,899 & 4 & 2.4 & 0.1 & 0.0 & 0.3 & 0.4 & 0.8 & 0.1 \\
\hline VA & 42,774 & 1 & 1.0 & 0.9 & 6.6 & 4.0 & 1.1 & 12.6 & 0.9 \\
\hline WA & 71,300 & 5 & 12.5 & 2.3 & 0.1 & 4.3 & 1.3 & 8.0 & 0.5 \\
\hline WI & 65,498 & 1 & 0.6 & 3.7 & 4.1 & 3.3 & 0.7 & 11.8 & 0.8 \\
\hline WY & 97,814 & 4 & 2.6 & 0.1 & 0.0 & 0.1 & 0.1 & 0.3 & 0.0 \\
\hline
\end{tabular}

\begin{tabular}{|l|l|l|}
\hline Totals & 102 & 262 \\
\hline
\end{tabular}
25 Mile Radius Limitation

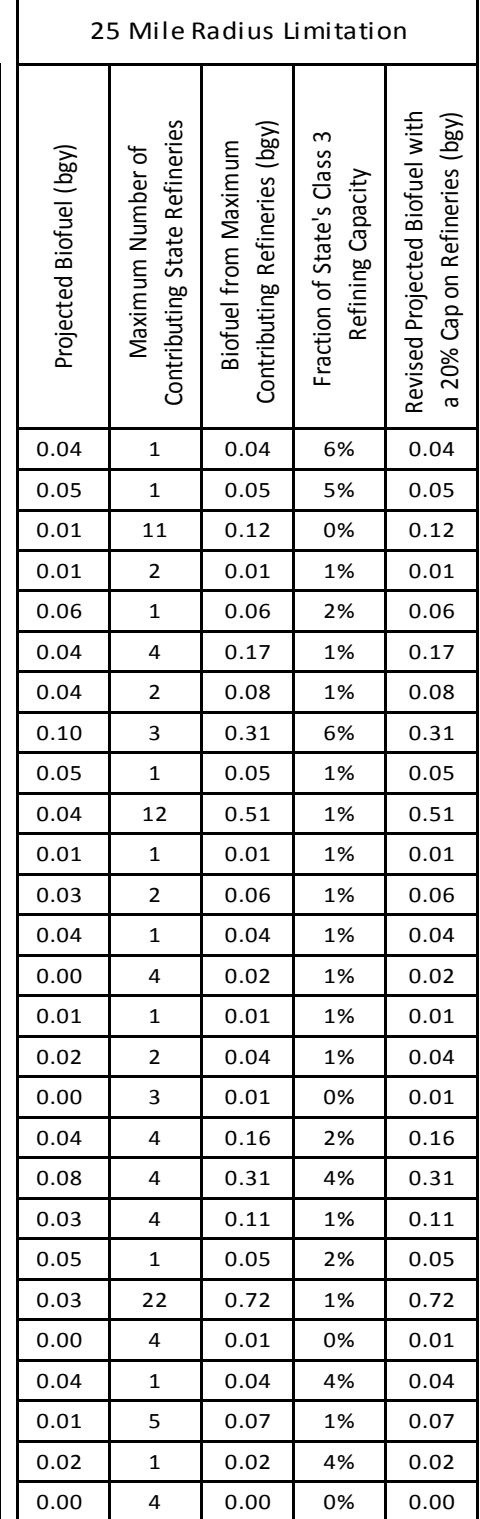

\begin{tabular}{|l|l|l|}
\hline Totals & 416 & 28.3 \\
\hline
\end{tabular}

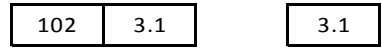

50 Mile Radius Limitation

\begin{tabular}{|c|c|c|c|c|}
\hline 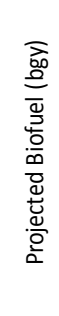 & 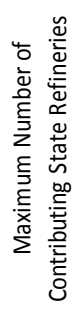 & 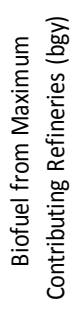 & 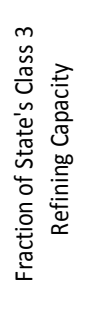 & 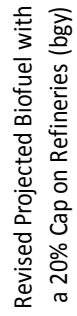 \\
\hline 0.14 & 1 & 0.14 & $24 \%$ & 0.12 \\
\hline 0.22 & 1 & 0.22 & $18 \%$ & 0.22 \\
\hline 0.04 & 11 & 0.47 & $2 \%$ & 0.47 \\
\hline 0.02 & 2 & 0.04 & $3 \%$ & 0.04 \\
\hline 0.23 & 1 & 0.23 & $8 \%$ & 0.23 \\
\hline 0.17 & 4 & 0.68 & $5 \%$ & 0.68 \\
\hline 0.16 & 2 & 0.31 & $5 \%$ & 0.31 \\
\hline 0.41 & 3 & 1.24 & $24 \%$ & 1.03 \\
\hline 0.20 & 1 & 0.20 & $5 \%$ & 0.20 \\
\hline 0.17 & 7 & 1.20 & $3 \%$ & 1.20 \\
\hline 0.05 & 1 & 0.05 & $3 \%$ & 0.05 \\
\hline 0.11 & 2 & 0.22 & $4 \%$ & 0.22 \\
\hline 0.18 & 1 & 0.18 & $3 \%$ & 0.18 \\
\hline 0.02 & 4 & 0.07 & $2 \%$ & 0.07 \\
\hline 0.05 & 1 & 0.05 & $6 \%$ & 0.05 \\
\hline 0.08 & 2 & 0.16 & $3 \%$ & 0.16 \\
\hline 0.01 & 3 & 0.02 & $1 \%$ & 0.02 \\
\hline 0.16 & 4 & 0.64 & $7 \%$ & 0.64 \\
\hline 0.31 & 4 & 1.25 & $17 \%$ & 1.25 \\
\hline 0.11 & 4 & 0.46 & $4 \%$ & 0.46 \\
\hline 0.21 & 1 & 0.21 & $7 \%$ & 0.21 \\
\hline 0.13 & 22 & 2.87 & $4 \%$ & 2.87 \\
\hline 0.01 & 4 & 0.02 & $1 \%$ & 0.02 \\
\hline 0.16 & 1 & 0.16 & $15 \%$ & 0.16 \\
\hline 0.06 & 5 & 0.30 & $2 \%$ & 0.30 \\
\hline 0.10 & 1 & 0.10 & $17 \%$ & 0.10 \\
\hline 0.00 & 4 & 0.01 & $0 \%$ & 0.01 \\
\hline
\end{tabular}

\begin{tabular}{l|l|l|}
\hline 97 & 11.5 & \\
\hline
\end{tabular}
100 Mile Radius Limitation

\begin{tabular}{|c|c|c|c|c|}
\hline 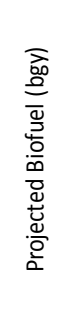 & 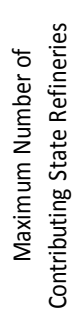 & 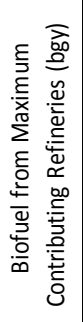 & 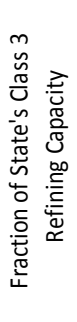 & 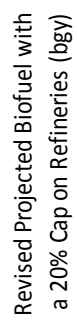 \\
\hline 0.58 & 1 & 0.58 & $98 \%$ & 0.12 \\
\hline 0.86 & 1 & 0.86 & $73 \%$ & 0.24 \\
\hline 0.17 & 6 & 1.02 & $4 \%$ & 1.02 \\
\hline 0.09 & 2 & 0.17 & $11 \%$ & 0.17 \\
\hline 0.90 & 1 & 0.90 & $32 \%$ & 0.56 \\
\hline 0.68 & 2 & 1.36 & $9 \%$ & 1.36 \\
\hline 0.63 & 2 & 1.26 & $19 \%$ & 1.26 \\
\hline 1.66 & 3 & 4.97 & $97 \%$ & 1.03 \\
\hline 0.78 & 1 & 0.78 & $21 \%$ & 0.73 \\
\hline 0.68 & 2 & 1.37 & $3 \%$ & 1.37 \\
\hline 0.20 & 1 & 0.20 & $12 \%$ & 0.20 \\
\hline 0.45 & 2 & 0.89 & $15 \%$ & 0.89 \\
\hline 0.70 & 1 & 0.70 & $13 \%$ & 0.70 \\
\hline 0.07 & 4 & 0.27 & $9 \%$ & 0.27 \\
\hline 0.21 & 1 & 0.21 & $23 \%$ & 0.18 \\
\hline 0.32 & 1 & 0.32 & $5 \%$ & 0.32 \\
\hline 0.03 & 3 & 0.09 & $4 \%$ & 0.09 \\
\hline 0.64 & 2 & 1.29 & $15 \%$ & 1.29 \\
\hline 1.25 & 3 & 3.75 & $52 \%$ & 1.44 \\
\hline 0.46 & 2 & 0.91 & $8 \%$ & 0.91 \\
\hline 0.84 & 1 & 0.84 & $30 \%$ & 0.56 \\
\hline 0.52 & 9 & 4.70 & $6 \%$ & 4.70 \\
\hline 0.02 & 3 & 0.06 & $3 \%$ & 0.06 \\
\hline 0.63 & 1 & 0.63 & $60 \%$ & 0.21 \\
\hline 0.24 & 3 & 0.72 & $6 \%$ & 0.72 \\
\hline 0.39 & 1 & 0.39 & $69 \%$ & 0.11 \\
\hline 0.01 & 4 & 0.03 & $1 \%$ & 0.03 \\
\hline
\end{tabular}

\begin{tabular}{|l|l|}
\hline 63 & 29.3 \\
\hline
\end{tabular}

20.5 
Table B.2. Candidate Class 3 Refineries for Biofuel Production (based on average state biomass projections and a $20 \%$ cap in refinery production)

\begin{tabular}{|c|c|c|c|}
\hline \multicolumn{4}{|c|}{ Refinery Information } \\
\hline Site & 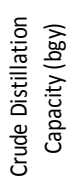 & 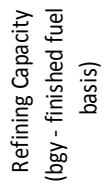 & 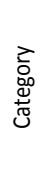 \\
\hline PONCA CITY, OK & 3.4 & 3.69 & $3 D$ \\
\hline CATLETTSBURG, KY & 3.4 & 3.63 & $3 D$ \\
\hline PASCAGOULA, MS & 5.0 & 5.31 & $3 D$ \\
\hline LAKE CHARLES, LA & 6.1 & 6.50 & $3 D$ \\
\hline GARYVILLE, LA & 7.0 & 7.48 & $3 D$ \\
\hline WOOD RIVER, IL & 5.3 & 5.62 & $3 D$ \\
\hline WHITING, IN & 5.9 & 6.35 & $3 \mathrm{D}$ \\
\hline DELAWARE CITY, DE & 2.6 & 2.81 & $3 D$ \\
\hline MEMPHIS, TN & 2.6 & 2.80 & $3 C$ \\
\hline TEXAS CITY, TX & 3.2 & 3.44 & $3 D$ \\
\hline TEXAS CITY, TX & 6.6 & 7.01 & $3 \mathrm{D}$ \\
\hline HOUSTON, TX & 4.2 & 4.46 & $3 D$ \\
\hline BAYTOWN, TX & 8.1 & 8.62 & $3 D$ \\
\hline PORT ARTHUR, TX & 3.3 & 3.54 & $3 D$ \\
\hline PORT ARTHUR, TX & 4.1 & 4.43 & $3 \mathrm{D}$ \\
\hline BEAUMONT, TX & 5.0 & 5.30 & $3 D$ \\
\hline PORT ARTHUR, TX & 5.7 & 6.13 & $3 D$ \\
\hline CORPUS CHRISTI, TX & 4.2 & 4.50 & $3 \mathrm{D}$ \\
\hline LEMONT, IL & 2.4 & 2.52 & $3 D$ \\
\hline LIMA, OH & 2.3 & 2.51 & $3 C$ \\
\hline TRAINER, PA & 2.6 & 2.80 & $3 D$ \\
\hline SAINT PAUL, MN & 4.4 & 4.72 & $3 D$ \\
\hline EL DORADO, KS & 1.9 & 2.07 & $3 \mathrm{D}$ \\
\hline COFFEYVILLE, KS & 1.7 & 1.77 & $3 D$ \\
\hline PAULSBORO, NJ & 2.3 & 2.45 & $3 \mathrm{D}$ \\
\hline MCPHERSON, KS & 1.2 & 1.29 & $3 C$ \\
\hline ARDMORE, OK & 1.2 & 1.28 & $3 C$ \\
\hline SAINT PAUL, MN & 1.2 & 1.25 & $3 D$ \\
\hline CANTON, OH & 1.2 & 1.25 & $3 \mathrm{D}$ \\
\hline FERNDALE, WA & 3.2 & 3.45 & $3 D$ \\
\hline FERNDALE, WA & 3.2 & 3.45 & $3 D$ \\
\hline ANACORTES, WA & 2.0 & 2.18 & $3 D$ \\
\hline EL DORADO, AR & 1.1 & 1.18 & $3 C$ \\
\hline TULSA EAST, OK & 1.0 & 1.11 & $3 C$ \\
\hline YORKTOWN, VA & 1.0 & 1.05 & $3 C$ \\
\hline WARREN, PA & 1.0 & 1.03 & $3 \mathrm{D}$ \\
\hline DETROIT, MI & 1.6 & 1.68 & $3 \mathrm{D}$ \\
\hline MANDAN, ND & 0.8 & 0.89 & $3 C$ \\
\hline WILMINGTON, CA & 2.0 & 2.17 & $3 D$ \\
\hline RICHMOND, CA & 3.5 & 3.80 & $3 D$ \\
\hline LOS ANGELES, CA & 3.7 & 3.93 & $3 D$ \\
\hline WILMINGTON, CA & 1.4 & 1.53 & $3 D$ \\
\hline EL SEGUNDO, CA & 4.0 & 4.24 & $3 D$ \\
\hline BENICIA, CA & 1.9 & 1.99 & $3 D$ \\
\hline TUSCALOOSA, AL & 0.6 & 0.59 & $3 B$ \\
\hline SUPERIOR, WI & 0.5 & 0.56 & $3 D$ \\
\hline COMMERCE CITYE, CO & 0.5 & 0.55 & $3 \mathrm{~A}$ \\
\hline COMMERCE CITY W, CO & 1.0 & 1.06 & $3 D$ \\
\hline MOUNT VERNON, IN & 0.4 & 0.41 & $3 C$ \\
\hline LAUREL, MT & 0.8 & 0.90 & $3 \mathrm{~A}$ \\
\hline BILLINGS, MT & 0.9 & 0.92 & $3 \mathrm{D}$ \\
\hline BILLINGS, MT & 0.9 & 0.92 & $3 \mathrm{D}$ \\
\hline GALLUP, NM & 0.3 & 0.34 & $3 C$ \\
\hline BLOOMFIELD, NM & 0.2 & 0.27 & $3 C$ \\
\hline ARTESIA, NM & 1.6 & 1.70 & $3 \mathrm{D}$ \\
\hline GREAT FALLS, MT & 0.1 & 0.16 & $3 D$ \\
\hline NORTH SALT LAKE, UT & 0.4 & 0.44 & $3 C$ \\
\hline SALT LAKE CITY, UT & 0.8 & 0.89 & $3 c$ \\
\hline SALT LAKE CITY, UT & 0.7 & 0.72 & $3 C$ \\
\hline CHEYENNE, WY & 0.7 & 0.77 & $3 C$ \\
\hline EVANSVILLE, WY & 0.4 & 0.38 & $3 C$ \\
\hline NEW CASTLE, WY & 0.2 & 0.21 & $3 C$ \\
\hline SINCLAIR, WY & 1.2 & 1.25 & $3 D$ \\
\hline
\end{tabular}

\begin{tabular}{|c|c|c|}
\hline \multicolumn{3}{|c|}{25 Mile Radius Limitation } \\
\hline 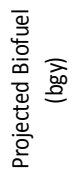 & 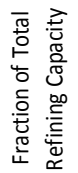 & 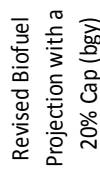 \\
\hline 0.078 & $2.1 \%$ & 0.078 \\
\hline 0.049 & $1.3 \%$ & 0.049 \\
\hline 0.044 & $0.8 \%$ & 0.044 \\
\hline 0.043 & $0.7 \%$ & 0.043 \\
\hline 0.043 & $0.6 \%$ & 0.043 \\
\hline 0.043 & $0.8 \%$ & 0.043 \\
\hline 0.039 & $0.6 \%$ & 0.039 \\
\hline 0.056 & $2.0 \%$ & 0.056 \\
\hline 0.053 & $1.9 \%$ & 0.053 \\
\hline 0.033 & $0.9 \%$ & 0.033 \\
\hline 0.033 & $0.5 \%$ & 0.033 \\
\hline 0.033 & $0.7 \%$ & 0.033 \\
\hline 0.033 & $0.4 \%$ & 0.033 \\
\hline 0.033 & $0.9 \%$ & 0.033 \\
\hline 0.033 & $0.7 \%$ & 0.033 \\
\hline 0.033 & $0.6 \%$ & 0.033 \\
\hline 0.033 & $0.5 \%$ & 0.033 \\
\hline 0.033 & $0.7 \%$ & 0.033 \\
\hline 0.043 & $1.7 \%$ & 0.043 \\
\hline 0.040 & $1.6 \%$ & 0.040 \\
\hline 0.028 & $1.0 \%$ & 0.028 \\
\hline 0.028 & $0.6 \%$ & 0.028 \\
\hline 0.104 & $5.0 \%$ & 0.104 \\
\hline 0.104 & $5.8 \%$ & 0.104 \\
\hline 0.020 & $0.8 \%$ & 0.020 \\
\hline 0.104 & $8.0 \%$ & 0.104 \\
\hline 0.078 & $6.1 \%$ & 0.078 \\
\hline 0.028 & $2.2 \%$ & 0.028 \\
\hline 0.040 & $3.2 \%$ & 0.040 \\
\hline 0.015 & $0.4 \%$ & 0.015 \\
\hline 0.015 & $0.4 \%$ & 0.015 \\
\hline 0.015 & $0.7 \%$ & 0.015 \\
\hline 0.054 & $4.6 \%$ & 0.054 \\
\hline 0.078 & $7.0 \%$ & 0.078 \\
\hline 0.039 & $3.8 \%$ & 0.039 \\
\hline 0.028 & $2.8 \%$ & 0.028 \\
\hline 0.013 & $0.7 \%$ & 0.013 \\
\hline 0.013 & $1.4 \%$ & 0.013 \\
\hline 0.011 & $0.5 \%$ & 0.011 \\
\hline 0.011 & $0.3 \%$ & 0.011 \\
\hline 0.011 & $0.3 \%$ & 0.011 \\
\hline 0.011 & $0.7 \%$ & 0.011 \\
\hline 0.011 & $0.3 \%$ & 0.011 \\
\hline 0.011 & $0.5 \%$ & 0.011 \\
\hline 0.036 & $6.1 \%$ & 0.036 \\
\hline 0.024 & $4.3 \%$ & 0.024 \\
\hline 0.005 & $1.0 \%$ & 0.005 \\
\hline 0.005 & $0.5 \%$ & 0.005 \\
\hline 0.039 & $9.7 \%$ & 0.039 \\
\hline 0.004 & $0.5 \%$ & 0.004 \\
\hline 0.004 & $0.5 \%$ & 0.004 \\
\hline 0.004 & $0.5 \%$ & 0.004 \\
\hline 0.002 & $0.6 \%$ & 0.002 \\
\hline 0.002 & $0.7 \%$ & 0.002 \\
\hline 0.002 & $0.1 \%$ & 0.002 \\
\hline 0.004 & $2.8 \%$ & 0.004 \\
\hline 0.001 & $0.3 \%$ & 0.001 \\
\hline 0.001 & $0.1 \%$ & 0.001 \\
\hline 0.001 & $0.2 \%$ & 0.001 \\
\hline 0.000 & $0.1 \%$ & 0.000 \\
\hline 0.000 & $0.1 \%$ & 0.000 \\
\hline 0.000 & $0.2 \%$ & 0.000 \\
\hline 0.000 & $0.0 \%$ & 0.000 \\
\hline & Total & 1.8 \\
\hline
\end{tabular}

\begin{tabular}{|c|c|c|}
\hline \multicolumn{3}{|c|}{50 Mile Radius Limitation } \\
\hline 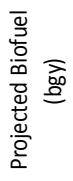 & 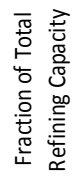 & 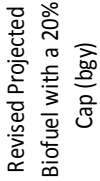 \\
\hline 0.313 & $8.5 \%$ & 0.313 \\
\hline 0.195 & $5.4 \%$ & 0.195 \\
\hline 0.176 & $3.3 \%$ & 0.176 \\
\hline 0.171 & $2.6 \%$ & 0.171 \\
\hline 0.171 & $2.3 \%$ & 0.171 \\
\hline 0.171 & $3.0 \%$ & 0.171 \\
\hline 0.157 & $2.5 \%$ & 0.157 \\
\hline 0.226 & $8.0 \%$ & 0.226 \\
\hline 0.210 & $7.5 \%$ & 0.210 \\
\hline 0.131 & $3.8 \%$ & 0.131 \\
\hline 0.131 & $1.9 \%$ & 0.131 \\
\hline 0.131 & $2.9 \%$ & 0.131 \\
\hline 0.131 & $1.5 \%$ & 0.131 \\
\hline 0.131 & $3.7 \%$ & 0.131 \\
\hline 0.131 & $3.0 \%$ & 0.131 \\
\hline 0.131 & $2.5 \%$ & 0.131 \\
\hline 0.131 & $2.1 \%$ & 0.131 \\
\hline 0.131 & $2.9 \%$ & 0.131 \\
\hline 0.171 & $6.8 \%$ & 0.171 \\
\hline 0.161 & $6.4 \%$ & 0.161 \\
\hline 0.114 & $4.1 \%$ & 0.114 \\
\hline 0.112 & $2.4 \%$ & 0.112 \\
\hline 0.414 & $20.0 \%$ & 0.413 \\
\hline 0.414 & $20.0 \%$ & 0.354 \\
\hline 0.080 & $3.3 \%$ & 0.080 \\
\hline 0.414 & $20.0 \%$ & 0.258 \\
\hline 0.313 & $20.0 \%$ & 0.257 \\
\hline 0.112 & $8.9 \%$ & 0.112 \\
\hline 0.161 & $12.9 \%$ & 0.161 \\
\hline 0.060 & $1.7 \%$ & 0.060 \\
\hline 0.060 & $1.7 \%$ & 0.060 \\
\hline 0.060 & $2.8 \%$ & 0.060 \\
\hline 0.216 & $18.3 \%$ & 0.216 \\
\hline 0.313 & $20.0 \%$ & 0.223 \\
\hline 0.157 & $15.0 \%$ & 0.157 \\
\hline 0.114 & $11.0 \%$ & 0.114 \\
\hline 0.050 & $3.0 \%$ & 0.050 \\
\hline 0.051 & $5.8 \%$ & 0.051 \\
\hline 0.043 & $2.0 \%$ & 0.043 \\
\hline 0.043 & $1.1 \%$ & 0.043 \\
\hline 0.043 & $1.1 \%$ & 0.043 \\
\hline 0.043 & $2.8 \%$ & 0.043 \\
\hline 0.043 & $1.0 \%$ & 0.043 \\
\hline 0.043 & $2.1 \%$ & 0.043 \\
\hline 0.144 & $20.0 \%$ & 0.118 \\
\hline 0.096 & $17.2 \%$ & 0.096 \\
\hline 0.022 & $3.9 \%$ & 0.022 \\
\hline 0.022 & $2.0 \%$ & 0.022 \\
\hline 0.157 & $20.0 \%$ & 0.081 \\
\hline 0.017 & $1.9 \%$ & 0.017 \\
\hline 0.017 & $1.9 \%$ & 0.017 \\
\hline 0.017 & $1.9 \%$ & 0.017 \\
\hline 0.008 & $2.3 \%$ & 0.008 \\
\hline 0.008 & $2.9 \%$ & 0.008 \\
\hline 0.008 & $0.5 \%$ & 0.008 \\
\hline 0.017 & $11.0 \%$ & 0.017 \\
\hline 0.005 & $1.2 \%$ & 0.005 \\
\hline 0.005 & $0.6 \%$ & 0.005 \\
\hline 0.005 & $0.7 \%$ & 0.005 \\
\hline 0.002 & $0.2 \%$ & 0.002 \\
\hline 0.002 & $0.4 \%$ & 0.002 \\
\hline 0.002 & $0.7 \%$ & 0.002 \\
\hline 0.002 & $0.1 \%$ & 0.002 \\
\hline & Total & 6.9 \\
\hline
\end{tabular}

\begin{tabular}{|c|c|c|}
\hline \multicolumn{3}{|c|}{100 Mile Radius Limitation } \\
\hline 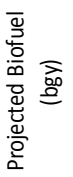 & 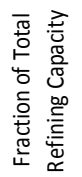 & 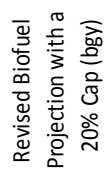 \\
\hline 1.252 & $20.0 \%$ & 0.738 \\
\hline 0.781 & $20.0 \%$ & 0.726 \\
\hline 0.703 & $13.2 \%$ & 0.703 \\
\hline 0.684 & $10.5 \%$ & 0.684 \\
\hline 0.684 & $9.1 \%$ & 0.684 \\
\hline 0.682 & $12.1 \%$ & 0.682 \\
\hline 0.628 & $9.9 \%$ & 0.628 \\
\hline 0.904 & $20.0 \%$ & 0.562 \\
\hline 0.841 & $20.0 \%$ & 0.561 \\
\hline 0.523 & $15.2 \%$ & 0.523 \\
\hline 0.523 & $7.5 \%$ & 0.523 \\
\hline 0.523 & $11.7 \%$ & 0.523 \\
\hline 0.523 & $6.1 \%$ & 0.523 \\
\hline 0.523 & $14.8 \%$ & 0.523 \\
\hline 0.523 & $11.8 \%$ & 0.523 \\
\hline 0.523 & $9.9 \%$ & 0.523 \\
\hline 0.523 & $8.5 \%$ & 0.523 \\
\hline 0.523 & $11.6 \%$ & 0.523 \\
\hline 0.682 & $20.0 \%$ & 0.503 \\
\hline 0.644 & $20.0 \%$ & 0.502 \\
\hline 0.456 & $16.2 \%$ & 0.456 \\
\hline 0.446 & $9.5 \%$ & 0.446 \\
\hline 1.657 & $20.0 \%$ & 0.413 \\
\hline 1.657 & $20.0 \%$ & 0.354 \\
\hline 0.321 & $13.1 \%$ & 0.321 \\
\hline 1.657 & $20.0 \%$ & 0.258 \\
\hline 1.252 & $20.0 \%$ & 0.257 \\
\hline 0.446 & $20.0 \%$ & 0.249 \\
\hline 0.644 & $20.0 \%$ & 0.249 \\
\hline 0.240 & $6.9 \%$ & 0.240 \\
\hline 0.240 & $6.9 \%$ & 0.240 \\
\hline 0.240 & $11.0 \%$ & 0.240 \\
\hline 0.865 & $20.0 \%$ & 0.236 \\
\hline 1.252 & $20.0 \%$ & 0.223 \\
\hline 0.629 & $20.0 \%$ & 0.209 \\
\hline 0.456 & $20.0 \%$ & 0.207 \\
\hline 0.202 & $12.0 \%$ & 0.202 \\
\hline 0.205 & $20.0 \%$ & 0.177 \\
\hline 0.170 & $7.8 \%$ & 0.170 \\
\hline 0.170 & $4.5 \%$ & 0.170 \\
\hline 0.170 & $4.3 \%$ & 0.170 \\
\hline 0.170 & $11.1 \%$ & 0.170 \\
\hline 0.170 & $4.0 \%$ & 0.170 \\
\hline 0.170 & $8.5 \%$ & 0.170 \\
\hline 0.576 & $20.0 \%$ & 0.118 \\
\hline 0.385 & $20.0 \%$ & 0.112 \\
\hline 0.086 & $15.6 \%$ & 0.086 \\
\hline 0.086 & $8.1 \%$ & 0.086 \\
\hline 0.628 & $20.0 \%$ & 0.081 \\
\hline 0.068 & $7.6 \%$ & 0.068 \\
\hline 0.068 & $7.5 \%$ & 0.068 \\
\hline 0.068 & $7.4 \%$ & 0.068 \\
\hline 0.031 & $9.2 \%$ & 0.031 \\
\hline 0.031 & $11.7 \%$ & 0.031 \\
\hline 0.031 & $1.8 \%$ & 0.031 \\
\hline 0.068 & $20.0 \%$ & 0.031 \\
\hline 0.021 & $4.8 \%$ & 0.021 \\
\hline 0.021 & $2.4 \%$ & 0.021 \\
\hline 0.021 & $2.9 \%$ & 0.021 \\
\hline 0.006 & $0.8 \%$ & 0.006 \\
\hline 0.006 & $1.7 \%$ & 0.006 \\
\hline 0.006 & $3.0 \%$ & 0.006 \\
\hline 0.006 & $0.5 \%$ & 0.006 \\
\hline & Total & 18.6 \\
\hline
\end{tabular}


Table B.3. Class 3 Refineries Removed from Candidate List (Table B.2) Due to Projected Limitations in State-Based Biomass

\begin{tabular}{|c|c|c|c|}
\hline \multicolumn{4}{|c|}{ Refinery Information } \\
\hline Site & 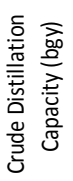 & 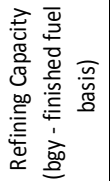 & 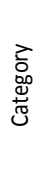 \\
\hline ANACORTES, WA & 3.48 & 3.72 & $3 D$ \\
\hline FERNDALE, WA & 3.52 & 3.76 & $3 D$ \\
\hline WOODS CROSS, UT & 7.22 & 7.72 & $3 C$ \\
\hline SUNRAY, TX & 3.59 & 3.84 & $3 C$ \\
\hline CORPUS CHRISTI, TX & 3.45 & 3.69 & $3 C$ \\
\hline BORGER, TX & 3.42 & 3.66 & $3 C$ \\
\hline CORPUS CHRISTI, TX & 2.97 & 3.17 & $3 C$ \\
\hline EL PASO, TX & 2.90 & 3.10 & $3 B$ \\
\hline THREE RIVERS, TX & 2.77 & 2.96 & $3 C$ \\
\hline BIG SPRING, TX & 4.69 & 5.02 & $3 B$ \\
\hline DEER PARK, TX & 3.59 & 3.84 & $3 C$ \\
\hline SWEENY, TX & 2.43 & 2.60 & $3 C$ \\
\hline PASADENA, TX & 2.41 & 2.58 & $3 \mathrm{~B}$ \\
\hline HOUSTON, TX & 2.68 & 2.86 & $3 \mathrm{~A}$ \\
\hline TEXAS CITY, TX & 4.90 & 5.24 & $3 \mathrm{~A}$ \\
\hline TYLER, TX & 2.28 & 2.44 & $3 C$ \\
\hline MARCUS HOOK, PA & 2.21 & 2.36 & $3 C$ \\
\hline PHILADELPHIA, PA & 2.12 & 2.27 & $3 \mathrm{D}$ \\
\hline WYNNEWOOD, OK & 2.01 & 2.16 & $3 D$ \\
\hline TOLEDO, OH & 1.79 & 1.92 & $3 D$ \\
\hline TOLEDO, OH & 1.77 & 1.89 & $3 \mathrm{D}$ \\
\hline LINDEN, NJ & 3.45 & 3.69 & $3 C$ \\
\hline WESTLAKE, LA & 1.47 & 1.57 & $3 \mathrm{~A}$ \\
\hline CONVENT, LA & 1.31 & 1.40 & $3 \mathrm{D}$ \\
\hline MERAUX, LA & 1.24 & 1.33 & $3 B$ \\
\hline KROTZ SPRINGS, LA & 1.72 & 1.85 & $3 C$ \\
\hline PORT ALLEN, LA & 1.48 & 1.59 & $3 C$ \\
\hline NORCO, LA & 1.15 & 1.23 & $3 \mathrm{~A}$ \\
\hline CHALMETTE, LA & 1.15 & 1.23 & $3 \mathrm{~A}$ \\
\hline BATON ROUGE, LA & 1.03 & 1.11 & $3 C$ \\
\hline BELLE CHASSE, LA & 0.97 & 1.03 & $3 D$ \\
\hline NORCO, LA & 0.90 & 0.96 & $3 C$ \\
\hline JOLIET, IL & 2.18 & 2.33 & $3 \mathrm{~A}$ \\
\hline ROBINSON, IL & 1.77 & 1.89 & $3 C$ \\
\hline MARTINEZ, CA & 2.35 & 2.51 & $3 C$ \\
\hline RODEO, CA & 2.15 & 2.30 & $3 C$ \\
\hline MARTINEZ, CA & 1.10 & 1.18 & $3 C$ \\
\hline TORRANCE, CA & 0.81 & 0.87 & $3 C$ \\
\hline WILMINGTON, CA & 0.36 & 0.39 & $3 B$ \\
\hline
\end{tabular}

\begin{tabular}{|c|c|c|}
\hline \multicolumn{3}{|c|}{25 Mile Radius Limitation } \\
\hline 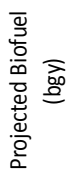 & 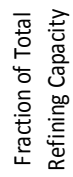 & 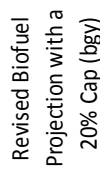 \\
\hline 0.043 & $1.1 \%$ & 0.043 \\
\hline 0.043 & $1.1 \%$ & 0.043 \\
\hline 0.043 & $0.6 \%$ & 0.043 \\
\hline 0.043 & $1.1 \%$ & 0.043 \\
\hline 0.043 & $1.2 \%$ & 0.043 \\
\hline 0.043 & $1.2 \%$ & 0.043 \\
\hline 0.043 & $1.3 \%$ & 0.043 \\
\hline 0.043 & $1.4 \%$ & 0.043 \\
\hline 0.043 & $1.4 \%$ & 0.043 \\
\hline 0.033 & $0.7 \%$ & 0.033 \\
\hline 0.033 & $0.9 \%$ & 0.033 \\
\hline 0.033 & $1.3 \%$ & 0.033 \\
\hline 0.040 & $1.6 \%$ & 0.040 \\
\hline 0.028 & $1.0 \%$ & 0.028 \\
\hline 0.028 & $0.5 \%$ & 0.028 \\
\hline 0.033 & $1.3 \%$ & 0.033 \\
\hline 0.040 & $1.7 \%$ & 0.040 \\
\hline 0.033 & $1.4 \%$ & 0.033 \\
\hline 0.033 & $1.5 \%$ & 0.033 \\
\hline 0.043 & $2.2 \%$ & 0.043 \\
\hline 0.033 & $1.7 \%$ & 0.033 \\
\hline 0.020 & $0.5 \%$ & 0.020 \\
\hline 0.033 & $2.1 \%$ & 0.033 \\
\hline 0.033 & $2.3 \%$ & 0.033 \\
\hline 0.033 & $2.5 \%$ & 0.033 \\
\hline 0.015 & $0.8 \%$ & 0.015 \\
\hline 0.015 & $0.9 \%$ & 0.015 \\
\hline 0.043 & $3.5 \%$ & 0.043 \\
\hline 0.033 & $2.7 \%$ & 0.033 \\
\hline 0.078 & $7.1 \%$ & 0.078 \\
\hline 0.033 & $3.2 \%$ & 0.033 \\
\hline 0.033 & $3.4 \%$ & 0.033 \\
\hline 0.011 & $0.5 \%$ & 0.011 \\
\hline 0.011 & $0.6 \%$ & 0.011 \\
\hline 0.011 & $0.4 \%$ & 0.011 \\
\hline 0.011 & $0.5 \%$ & 0.011 \\
\hline 0.011 & $0.9 \%$ & 0.011 \\
\hline 0.043 & $4.9 \%$ & 0.043 \\
\hline 0.001 & $0.3 \%$ & 0.001 \\
\hline
\end{tabular}

\begin{tabular}{|c|c|c|}
\hline \multicolumn{3}{|c|}{50 Mile Radius Limitation } \\
\hline 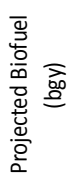 & 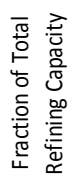 & 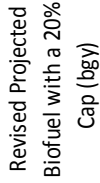 \\
\hline 0.171 & $4.6 \%$ & 0.171 \\
\hline 0.171 & $4.5 \%$ & 0.171 \\
\hline 0.171 & $2.2 \%$ & 0.171 \\
\hline 0.171 & $4.5 \%$ & 0.171 \\
\hline 0.171 & $4.6 \%$ & 0.171 \\
\hline 0.171 & $4.7 \%$ & 0.171 \\
\hline 0.171 & $5.4 \%$ & 0.171 \\
\hline 0.171 & $5.5 \%$ & 0.171 \\
\hline 0.171 & $5.8 \%$ & 0.171 \\
\hline 0.131 & $2.6 \%$ & 0.131 \\
\hline 0.131 & $3.4 \%$ & 0.131 \\
\hline 0.131 & $5.0 \%$ & 0.131 \\
\hline 0.161 & $6.2 \%$ & 0.161 \\
\hline 0.114 & $4.0 \%$ & 0.114 \\
\hline 0.114 & $2.2 \%$ & 0.114 \\
\hline 0.131 & $5.4 \%$ & 0.131 \\
\hline 0.161 & $6.8 \%$ & 0.161 \\
\hline 0.131 & $5.7 \%$ & 0.131 \\
\hline 0.131 & $6.1 \%$ & 0.131 \\
\hline 0.171 & $8.9 \%$ & 0.171 \\
\hline 0.131 & $6.9 \%$ & 0.131 \\
\hline 0.080 & $2.2 \%$ & 0.080 \\
\hline 0.131 & $8.3 \%$ & 0.131 \\
\hline 0.131 & $9.3 \%$ & 0.131 \\
\hline 0.131 & $9.8 \%$ & 0.131 \\
\hline 0.060 & $3.3 \%$ & 0.060 \\
\hline 0.060 & $3.8 \%$ & 0.060 \\
\hline 0.171 & $14.0 \%$ & 0.171 \\
\hline 0.131 & $10.7 \%$ & 0.131 \\
\hline 0.313 & $20.0 \%$ & 0.221 \\
\hline 0.131 & $12.6 \%$ & 0.131 \\
\hline 0.131 & $13.6 \%$ & 0.131 \\
\hline 0.043 & $1.8 \%$ & 0.043 \\
\hline 0.043 & $2.2 \%$ & 0.043 \\
\hline 0.043 & $1.7 \%$ & 0.043 \\
\hline 0.043 & $1.8 \%$ & 0.043 \\
\hline 0.043 & $3.6 \%$ & 0.043 \\
\hline 0.171 & $19.6 \%$ & 0.171 \\
\hline 0.005 & $1.4 \%$ & 0.005 \\
\hline
\end{tabular}

\begin{tabular}{|c|c|c|}
\hline \multicolumn{3}{|c|}{100 Mile Radius Limitation } \\
\hline 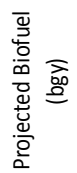 & 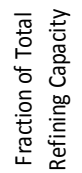 & 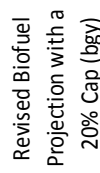 \\
\hline 0.684 & $18.4 \%$ & 0.684 \\
\hline 0.684 & $18.2 \%$ & 0.684 \\
\hline 0.684 & $8.9 \%$ & 0.684 \\
\hline 0.684 & $17.8 \%$ & 0.684 \\
\hline 0.684 & $18.5 \%$ & 0.684 \\
\hline 0.682 & $18.6 \%$ & 0.682 \\
\hline 0.682 & $20.0 \%$ & 0.635 \\
\hline 0.684 & $20.0 \%$ & 0.620 \\
\hline 0.684 & $20.0 \%$ & 0.593 \\
\hline 0.523 & $10.4 \%$ & 0.523 \\
\hline 0.523 & $13.6 \%$ & 0.523 \\
\hline 0.523 & $20.0 \%$ & 0.520 \\
\hline 0.644 & $20.0 \%$ & 0.517 \\
\hline 0.456 & $15.9 \%$ & 0.456 \\
\hline 0.456 & $8.7 \%$ & 0.456 \\
\hline 0.523 & $20.0 \%$ & 0.487 \\
\hline 0.644 & $20.0 \%$ & 0.472 \\
\hline 0.523 & $20.0 \%$ & 0.455 \\
\hline 0.523 & $20.0 \%$ & 0.431 \\
\hline 0.684 & $20.0 \%$ & 0.384 \\
\hline 0.523 & $20.0 \%$ & 0.378 \\
\hline 0.321 & $8.7 \%$ & 0.321 \\
\hline 0.523 & $20.0 \%$ & 0.314 \\
\hline 0.523 & $20.0 \%$ & 0.280 \\
\hline 0.523 & $20.0 \%$ & 0.266 \\
\hline 0.240 & $13.0 \%$ & 0.240 \\
\hline 0.240 & $15.1 \%$ & 0.240 \\
\hline 0.684 & $20.0 \%$ & 0.245 \\
\hline 0.523 & $20.0 \%$ & 0.245 \\
\hline 1.252 & $20.0 \%$ & 0.221 \\
\hline 0.523 & $20.0 \%$ & 0.207 \\
\hline 0.523 & $20.0 \%$ & 0.192 \\
\hline 0.170 & $7.3 \%$ & 0.170 \\
\hline 0.170 & $9.0 \%$ & 0.170 \\
\hline 0.170 & $6.8 \%$ & 0.170 \\
\hline 0.170 & $7.4 \%$ & 0.170 \\
\hline 0.170 & $14.4 \%$ & 0.170 \\
\hline 0.684 & $20.0 \%$ & 0.174 \\
\hline 0.021 & $5.4 \%$ & 0.021 \\
\hline & Total & 15.4 \\
\hline
\end{tabular}




\section{Appendix C. Description of Key Refinery Unit Operations}

Figure D.1 shows a generic flow diagram for a crude oil refinery. The primary unit operations include atmospheric distillation, vacuum distillation, gas processing, hydrotreating, isomerization, catalytic reforming, hydrocracking, catalytic cracking, and thermal cracking (or coking). Table D.1 gives a general description of the main unit operations. The subsequent sections give more detail to key unit operations.

Figure D.1. A Typical Refinery Flow Diagram Refinery Diagram http://en.wikipedia.org/wiki/Refinery

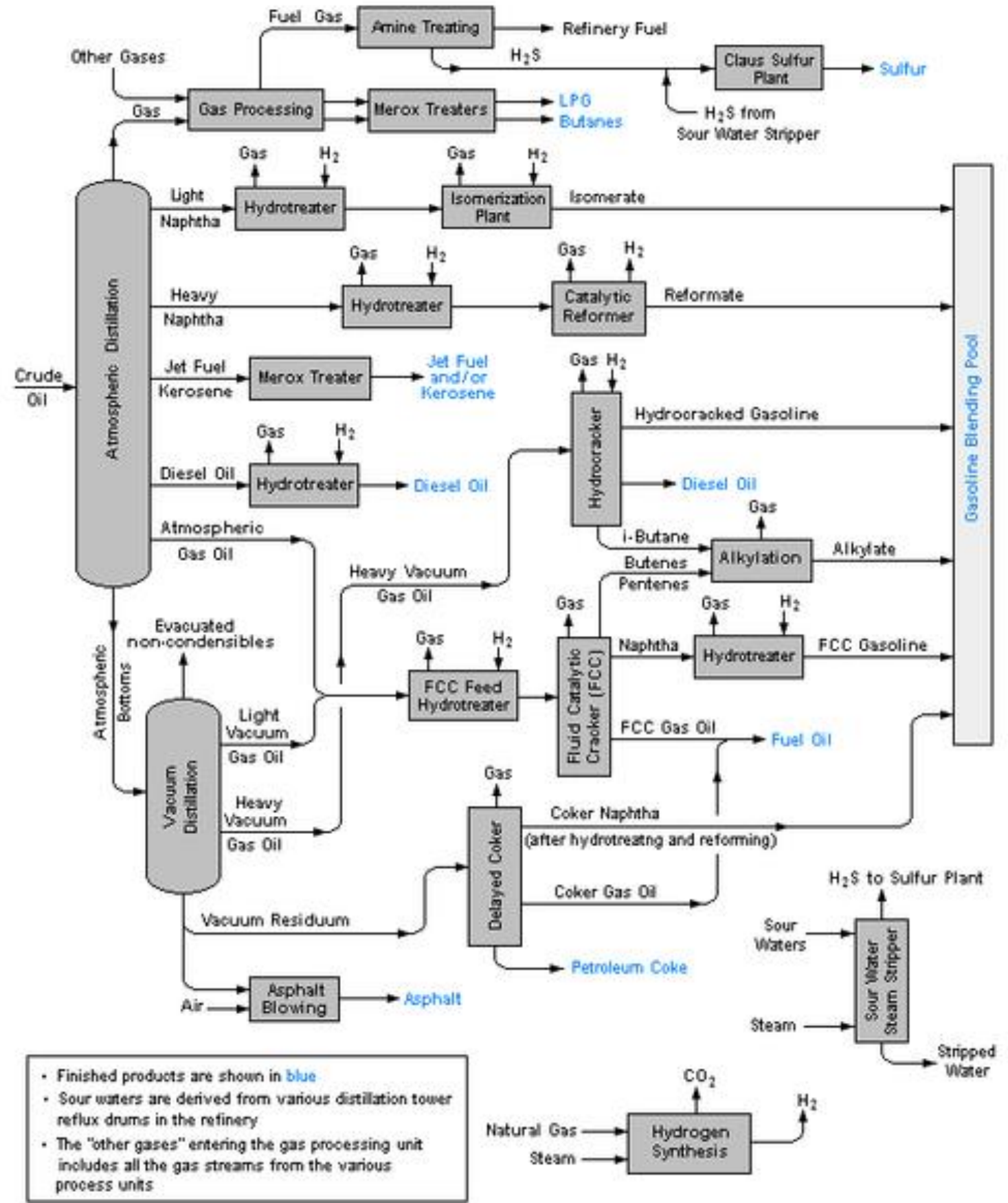

Page 31 
Table D.1. Descriptions of the Functions of each Unit Operation

\begin{tabular}{|c|c|}
\hline Unit Operation & Function \\
\hline Desalter & Washes out the crude oil before it enters the atmospheric distillation unit. \\
\hline $\begin{array}{l}\text { Atmospheric } \\
\text { Distillation }\end{array}$ & Distills crude oil into fractions - all incoming crude goes through this unit. \\
\hline Vacuum Distillation & $\begin{array}{l}\text { Further distills residual bottoms from atmospheric distillation. Vacuum gas } \\
\text { oils are processed in a hydrocracker or catalytic cracker to produce gasoline, } \\
\text { jet, and diesel fuels. Heavier oils can be used as feedstocks for lubricating } \\
\text { oil processing units. Residuum vacuum still bottoms can be processed in a } \\
\text { visbreaker, coker, or deasphalting unit to produce heavy oil or cracking or } \\
\text { lube base stocks. }\end{array}$ \\
\hline Naphtha Hydrotreater & $\begin{array}{l}\text { Uses hydrogen to desulfurize naphtha stream out of atmospheric distillation. } \\
\text { Catalytic reformer units require hydrotreating feed. }\end{array}$ \\
\hline Catalytic Reformer & $\begin{array}{l}\text { Converts naphtha-boiling range molecules into higher octane reformate } \\
\text { (reformer product). The reformate has higher content of aromatics and cyclic } \\
\text { hydrocarbons. An important byproduct of a reformer is hydrogen released } \\
\text { during the catalyst reaction. The hydrogen is used either in the } \\
\text { hydrotreaters or the hydrocracker. }\end{array}$ \\
\hline Distillate Hydrotreater & Desulfurizes distillates (such as diesel) after atmospheric distillation. \\
\hline Fluid Catalytic Cracker & Upgrades heavier fractions into lighter, more valuable products. \\
\hline Hydrocracker & $\begin{array}{l}\text { Uses hydrogen to upgrade heavier fractions into lighter, more valuable } \\
\text { products. }\end{array}$ \\
\hline Visbreaker & $\begin{array}{l}\text { Upgrades heavy residual oils by thermally cracking them into lighter, more } \\
\text { valuable reduced viscosity products. }\end{array}$ \\
\hline Merox Unit & $\begin{array}{l}\text { Treats LPG, kerosene or jet fuel by oxidizing mercaptans to organic } \\
\text { disulfides. }\end{array}$ \\
\hline Coking Units & $\begin{array}{l}\text { Includes delayed coking, fluid coker, and flexicoker. Processes heavy } \\
\text { residual oils into gasoline and diesel fuel, leaving petroleum coke as a } \\
\text { residual product. }\end{array}$ \\
\hline Alklyation Unit & Produces high-octane component for gasoline blending. \\
\hline Dimerization Unit & $\begin{array}{l}\text { Converts olefins into higher-octane gasoline blending components. For } \\
\text { example, butenes can be dimerized into isooctene which may subsequently } \\
\text { be hydrogenated to form isooctane. There are also other uses for } \\
\text { dimerization. }\end{array}$ \\
\hline Isomerization Unit & $\begin{array}{l}\text { Converts linear molecules to higher-octane branched molecules for blending } \\
\text { into gasoline or feed to alkylation units. }\end{array}$ \\
\hline Steam Reforming Unit & Produces hydrogen for the hydrotreaters or hydrocracker. \\
\hline $\begin{array}{l}\text { Amine Gas Treater, } \\
\text { Claus Unit, and Tail Gas } \\
\text { Treatment }\end{array}$ & Converts hydrogen sulfide from hydrodesulfurization into elemental sulfur. \\
\hline Solvent Refining Units & $\begin{array}{l}\text { Use solvent such as cresol or furfural to remove unwanted, mainly aromatics } \\
\text { from lubricating oil stock or diesel stock. }\end{array}$ \\
\hline Solvent Dewaxing Unit & Removes the heavy waxy constituents from vacuum distillation products. \\
\hline
\end{tabular}




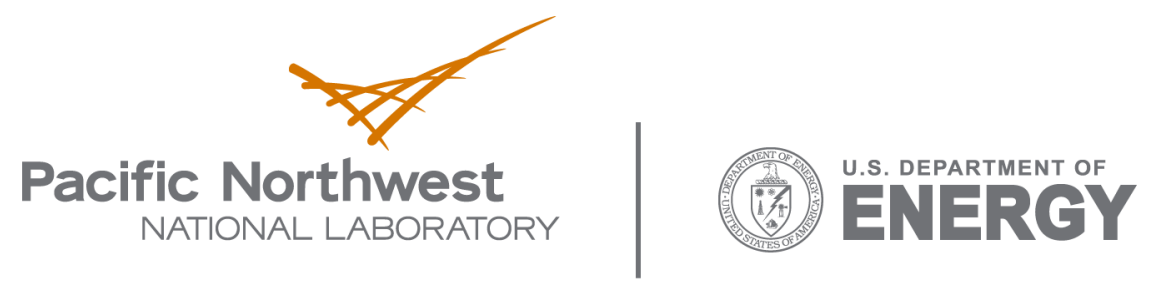

902 Battelle Boulevard

P.O. Box 999

Richland, WA 99352

1-888-375-PNNL (7665)

www.pnl.gov 